\title{
Land Use Land Cover Change Detection and Deforestation Modeling: In Delomena District of Bale Zone, Ethiopia
}

\author{
Girma Ayele ${ }^{1}$, Hussein Hayicho ${ }^{2 *}$, Mersha Alemu² \\ ${ }^{1}$ Farm Africa, Addis Ababa, Ethiopia \\ ${ }^{2}$ Department of Geography and Environmental Studies, Madda Walabu University, Bale Robe, Ethiopia \\ Email: girmaayele35@gmail.com, *hussienhayicho2000@gmail.com
}

How to cite this paper: Ayele, G., Hayicho, H. and Alemu, M. (2019) Land Use Land Cover Change Detection and Deforestation Modeling: In Delomena District of Bale Zone, Ethiopia. Journal of Environmental Protection, 10, 532-561. https://doi.org/10.4236/jep.2019.104031

Received: January 31, 2019

Accepted: April 8, 2019

Published: April 11, 2019

Copyright $\odot 2019$ by author(s) and Scientific Research Publishing Inc. This work is licensed under the Creative Commons Attribution International License (CC BY 4.0).

http://creativecommons.org/licenses/by/4.0/

\begin{abstract}
Previous studies in Delo-Mena district failed to provide conceptual framework about causes and impacts of deforestation including prediction of spatial location of future deforestation. The study was aimed at investigating spatiotemporal dynamics and prediction of future trends of deforestation in this area. Three periods Landsat images were downloaded and preprocessed using ENVI 4.3. Supervised classification technique was employed for image classification. Land Change Modular used to predict deforestation based on transition between 2000 and 2015 along three driving variables (road distance, settlement and soil). Six land-use land-cover classes were classified for three periods. The result indicated that the forest areas were 91,339, 73,274 and 70,481 hectors in year 2000, 2010 and 2015, respectively. This forest area was reduced by $20 \%$ between 2000 and 2010 at annual rate of $2 \%$. Between 2010 and 2015 , a forest area was lost by $4 \%$ with annual rate of $1 \%$. This deforestation rate was greater than global rates and was lower than rates of south eastern African countries. Farmland expansion was a major cause of deforestation contributed to the annual forest loss by $4.9 \%$ and $36 \%$ over different periods. In 2030, about 33,243 hectors of a forest area would be expected to disappear that implied emission of about 17 million ton of carbon dioxide. Fuelwoods shortage and loss of biodiversity were perceived as impacts of deforestation. Farmland and settlement were found increasing at expense of vegetation. Forest plantation, supply of fuel efficient technology and community mobilization were recommended that would be emphasized by the forestry sector based at the district office.
\end{abstract}

\section{Keywords}

Deforestation, LULC, Modeling, Transitions, Land Change Modular 


\section{Introduction}

Land-use land-cover change has become serious environmental concern at the local, regional and global scales [1] [2] [3]. For thousands of years, human activities on land have been grown significantly and changing the entire landscapes while most of changes have occurred in the tropics [4] [5]. For instance, between 1700 and 1990, global forest coverage was gradually decreased from 53.3 to 43.5 million $\mathrm{km}^{2}$ in favoring of cropland [6]. In 1990, the global forest cover was estimated at 4128 million hectors but was reduced to 3999 million hectors by 2015 [7]. During last three centuries, about 1.2 million $\mathrm{km}^{2}$ of forests lands and 5.6 million $\mathrm{km}^{2}$ of grasslands areas were disappeared while the cropland areas were increased by 12 million $\mathrm{km}^{2}$ [8].

Changes in land-use land-cover play important roles in global environmental change, because the changes have clearly affected the sustainability, biodiversity and interactions between the earth and atmosphere [2] [3]. For instance, conversions of different land-covers have contributed to release of carbon dioxide approximately equivalent to $30 \%$ of the fossil fuels [9] [10]. According to IPCC estimate, 1.6 billion tons of carbon dioxide was released annually over the last decades in connection to land-cover conversion as IPCC cited in [11]. Land-use land-cover change also affects hydrological system through influencing a rate of water infiltration and runoff [12].

Land-use land-cover change has been also challenging in Ethiopia. In the beginning of $19^{\text {th }}$ century, $40 \%$ of a land in the country was covered by forests [9] [13] [14]. However, a rapid rate of deforestation and land degradation led to a loss of plant and animal species. For instance, studies conducted in the highland areas of the country indicated that there was a loss of over 1.5 billion tons of topsoil annually as a result of erosion which implied for a soil loss of 35 to 40 tons per hectare in a year. In other words, it was equivalent to the loss of 1 to 1.6 million tons of grain per annum in the country [9] [15].

Gathering historical patterns of change and modeling it helps for better understanding of processes of change that helps to improve a land management practice [16] [17] [18]. A range of models of land-use land-cover change were developed to assess the past dynamics of change and predict future scenarios [3] [19]. Among plenty of these models, Land Change Modular (LCM) that is embedded in the IDRS selva is widely employed [3]. This is because it contains tools that help users to map change in the landscape, identification of transitions between land classes and predict future scenario with integration of user-specified deriving factors of change [17] [20] [21].

Land-use land-cover change particularly deforestation was challenging in the Bale Mountains Eco-region of Ethiopia which is the second large forest block in the country. For instance, [22] reported farmland increase by 7\% between 1973 and 1987 and 17\% between 1987 and 2000. This increase in the farmland area was occurred at the expense of Afro-alpine vegetation. Besides to this, annual deforestation rate of $1.1 \%$ for moist forest and $6.6 \%$ for dry land forest of the 
Bale mountains were detected between 2000 and 2011 [23].

Similarly, in Delo Mena District which is the part of Bale eco region has faced similar problem of deforestation. The study conducted in Delo Mena, Herena, Adaba and Dinsho Districts revealed that a forest land was decreased by $7 \%$ between 1986 and 2006 [24]. Specifically, the study conducted in the Delo Mena District revealed that the forest area was reduced by 5\% in year 2006 against the forest area existed in 1986 [25].

Those studies could quantify the land-use land-cover changes using remote sensing tools; however, they could not provide explanations about causative force of deforestation and associated impacts. In addition to this, those studies did not provide prediction about the future trends of change which would have importance to support resources managers in the process of taking appropriate actions. Therefore, the aim of this study was to investigate the extent and rate of the land-use land-cover change for three periods, predict the possible scenario of deforestation that would result in year 2030 and assess socio-economic drivers of deforestation and associated impacts.

\section{The Study Area and Research Methods}

\subsection{Description of Delo Mena District}

Delo Mena District is located in the Oromia National Regional State in the Bale Administrative Zone, Ethiopia. Geographically, it lies between $5^{\circ} 91^{\prime}$ to $6^{\circ} 71^{\prime} \mathrm{N}$ latitude and $39^{\circ} 87^{\prime}$ to $40^{\circ} 26^{\prime} \mathrm{E}$ longitude (Figure 1 ). Mena the capital town of the

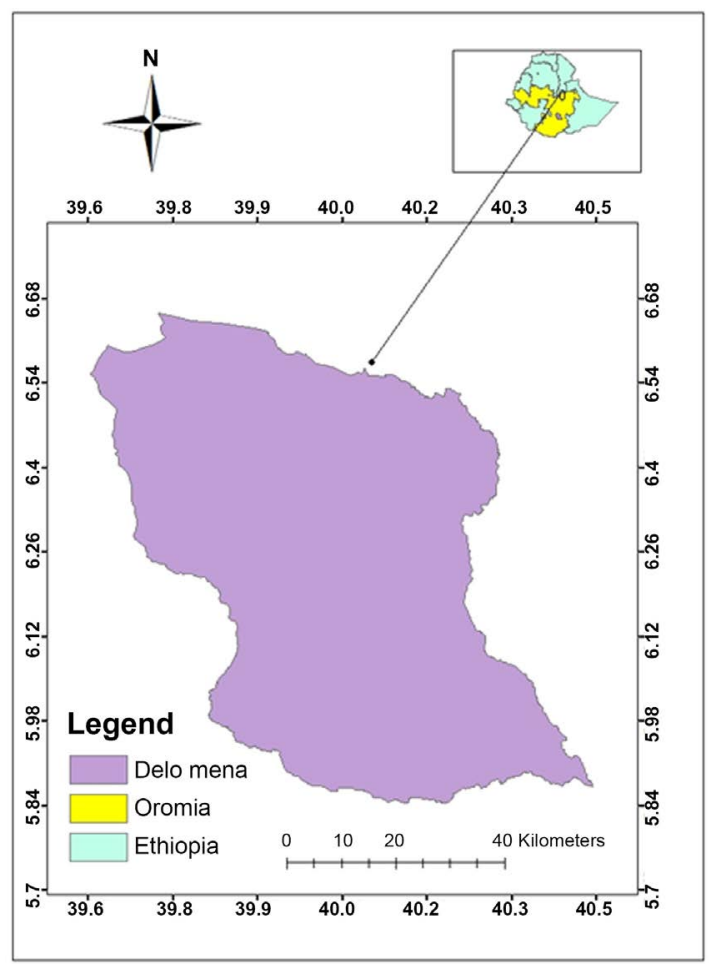

Figure 1. Location of study area in respect to national and regional positions. Source: Own processed map based on Ethio-GIS data. 
district locates south of Robe town at the distance of $125 \mathrm{~km}$ or it is found at 555 $\mathrm{km}$ to the southeast of Addis Ababa, the capital city of Ethiopia [26] [27]. The District covers 483,335 hectares.

\subsection{Land Use Land Cover of the Study Area}

In 2011 the land-use land-cover types of the District were described as a woodland, forest, grassland with a proportion of $59 \%, 16 \%, 21 \%$, respectively and the remaining 4\% was occupied by a farmland and settlement [28]. The forest of Delo Mena District comprises dominant forest tree species like Podocarpus falcate, Warburgia ugandensis, Celtis africana, Diospyros abyssinica, Syzgium guineense, Filicium decipiens. Similarly, a woodland forest comprises woody vegetation such as Terminalia species, Combretu mmolle, Syzgium macrocarpum and Acacia species [29].

The altitude of the district ranges from 500 to 2464 meter above sea level and it increases from the south to north and from west to east. About $64 \%$ of the land is characterized as flat with slope less than 10\% [30]. The major rivers that cross the district include Yadot, Deyu, Helgol, Erbaguda and Erba Kela. Some of these rivers are used for irrigation while the others serve for domestic and livestock services. Chromic vertisol, Pellicvertisols, Chromic fluvisol and Eutricfluvisol are the dominant soil types in the district. The chromic vertisol covers $58 \%$ of the coverage of the district and followed by Pellicvertisols (23\%) type that found in the northern part of the district+.

The district experiences bimodal rainfall type with the minimum of 628 millimeter and maximum of 775 millimeter per annum. The first rainfall season is a bit longer and extends from the April to June. The second season starts in the middle of September and ends at the beginning of November. Mean annual temperature is $29.5^{\circ} \mathrm{C}$ while the minimum and maximum temperature of $21^{\circ} \mathrm{C}$ and $38^{\circ} \mathrm{C}$ recorded respectively as [27].

According to prediction of [31] the population of Delo Mena District was 111,823 people with 56,642 males and 55,181 females. Of the total 96,145 in 2015 people are the dwellers of rural while the remaining live at urban area. Rural people have mainly engaged in agriculture activities like production of maize, teff, sorghum, chickpeas and haricot beans. Additionally, they produce cash crops such as coffee, chat, sugarcane and different fruits. Besides crops production, the rural community was engaged in livestock rearing in which cattle, goats, and equines were the dominant [30].

\subsection{Image Data Acquisition and Processing Procedures}

Landsat imager usually employed to analysis land-use land-cover dynamics [15] [32] [33]. In this study, three cloud free Landsat images for years 2000, 2010, and 2015 downloaded free of charge from Earth Explorer. Imageries of different anniversary dates cannot provide reliable result due variation of features' reflectance at different season [34]. Cognizant to this fact, images of same anniversary season were considered to minimize reflectance variation and descriptions of 
these images are presented in Table 1.

Image preprocessing required to correct some geometric and radiometric distortion that may be happen by remote sensing technology in association with rotation of earth, platform instability and atmospheric effect [34]. Pre-processing techniques includes geometric correction, georeferencing and image enhancement [35]. Preprocessing technique in this study was conducted using ENVI 4.3 software. Accordingly, Landsat image of each year projected to UTM 37 north and WGS84. Projected image of each year was clipped using the boundary shape file of Delo Mena District. Image enhancement was conducted to improve visibility and interpretability of each image as described in [36].

Supervised classification with a maximum likelihood algorithm was employed to classify the images of years 2000, 2010 and 2015. The training sites of each year digitized from selected bands using digitizing tools available in IDRSI software. Band-3 of each respective image was employed to digitize training sites because of its visibility as compared to other bands. Classification scheme of [37] was adopted for this study purpose with slight modification. Accordingly, six major land-use land-cover classes (forest, farm land, shrubs, settlements, wood land and bare land) identified for land use and land cover change analysis. Descriptions of each class are summarized in Table 2. Each raster classification converted to shape file format using arc GIS 10 to produce visible maps.

Table 1. Description of Landsat imagery.

\begin{tabular}{ccccc}
\hline Satellite type & Spatial Resolution & WRS Path/raw & Sensor Type & Date Acquisition Date \\
\hline Landsat-7 & $30 \mathrm{~m}$ & $167 / 056$ & ETM & 14 February, 2000 \\
Landsat-5 & $30 \mathrm{~m}$ & $167 / 056$ & TM+ & 02 December, 2010 \\
Landsat-8 & $30 \mathrm{~m}$ & $167 / 056$ & OLI_TIRS & 15 February, 2015 \\
\hline
\end{tabular}

Source: Earth Explorer-USGS archive at https://earthexplorer.usgs.gov/login/.

Table 2. Land-use and land-cover classes of the study area.

\begin{tabular}{|c|c|}
\hline Land categories & Descriptions of Land-Uses and Land-Cover types \\
\hline Forest & $\begin{array}{l}\text { Vegetation with canopy covers greater than } 20 \% \text { with tree height taller than } 15 \\
\text { meters which occupies greater than } 0.5 \text { ha. This comprises forest species of the } \\
\text { study area such as Podocarpus falcate, Warburgiau gandensis, Celtis africana, } \\
\text { Diospyros abyssinica }\end{array}$ \\
\hline Woodland & $\begin{array}{l}\text { Vegetation with canopy covers greater than } 15 \% \text { and a tree height } 5 \text { - } 15 \text { meters } \\
\text { were considered woodland. Woodland tree species in the study area comprises } \\
\text { Terminalia sp., Combretu mmolle, Syzgium macrocarpum and Acacia (Dereje } \\
\text { and Fekadu, 2001) }\end{array}$ \\
\hline Farmland & $\begin{array}{l}\text { This land-use encompasses areas that allocated for production of perennial and } \\
\text { seasonal crops in the rural areas }\end{array}$ \\
\hline Shrub land & This Land-cover category includes small woody plants and herbaceous plants \\
\hline Settlement & $\begin{array}{l}\text { Land feature such as towns and concentrated small rural villages that roofed with } \\
\text { corrugated iron sheets, scarp land and sandy areas }\end{array}$ \\
\hline Bare land & This class includes objects like rocky places without any vegetation \\
\hline
\end{tabular}

Source: Adapted with modification from [38]. 
For accuracy assessment of LULC map of year 2015, ground based data per land-class were collected using GPS whereas accuracy assessment data for images of 2000 and 2010 were generated from Google earth and topographic sheet. Flowingly, accuracy assessment data from a field used to consider as testing sites as a ground truth while a classified map of 2015 used as a categorical map in the tab of accuracy assessment of IDRSI software. Similar procedure was applied to assess accuracy of LULC maps of 2000 and 2010.

\subsubsection{Extent and Rate of Changes}

Change detection is a process in which aerial extent and spatial distribution of land features of two periods is analyzed [11] [39] [40] [41]. Change detection in this study was conducted for two periods. The first period range between 2000 and 2010. The second was between 2010 and 2015. The extent of change and rate of changes calculated following equation employed in [30].

Land change Modular tab used to analysis change detections in terms of gain, loss, net change and net contribution based on land-use land-cover maps of two different periods [11]. Contribution to the net change explains the question about which class is changed to what and by how much to provide complete picture of land-use land-cover dynamics [41] [42]. Transitions detection in this study was conducted for two periods. The first period covers transitions that occurred between 2000 and 2010 whereas the second included transitions that moved from 2010 to 2015 . In this study a contribution to net change analysis conducted only for a forest because the forest is the main focus of this study

\subsubsection{Techniques of Deforestation Modeling}

The transition from the forest class to other classes like a farmland, shrubs, settlement and woodland generated based on LULC maps of 2000 and 2010 using LCM. Those four transitions were added to transition sub-model and named as the deforestation that referred to as the categorical dependent variable. The maximum number of transitions is equal to a number of classes indicated in input maps [11] [43]. However, in this study only four transitions were considered while the transition from forest to bare land was not considered because its transition found insignificant (Table 3).

\subsubsection{Determination of Deriving Factors of Deforestation}

Determination of deriving factors is prerequisite step to conduct future prediction

Table 3. Transition of Sub-model of deforestation.

\begin{tabular}{cccc}
\hline & From: & To: & Sub-Model Name \\
\hline yes & forest & farm land & deforestation \\
yes & forest & shrubs & deforestation \\
yes & forest & settlements & deforestation \\
yes & forest & woodlands & deforestation \\
no & forest & bare land & Farm to forest \\
\hline
\end{tabular}

Source: Own analysis using IDRSI software. 
[44] [45] because model is a tool to analyze relationship between deforestation and associated derivers [46]. Deforestation can be influenced by spatial factors such as elevation, slope, roads and soil type [47] [48]. Moreover, it has remarked that gentle slope, soil fertility, proximity to settlement and water sources are favorable conditions that attract people to convert more vegetation to farmland areas [11] [49]. A part from this, it is noted that selection of the spatial variables heavily depends on availability of reliable data and ability of variables to express past and future dynamics [35] [50]. Considering this fact, six deriving factors considered like elevation, slope, soil, road, settlement and river. Hence a digital elevation models with 30-meter resolution downloaded from the ASTER's website using link http://gdem.ersdac.jspacesytems.or.jp. It was projected to WGP-84 and 37 North. Geo-referencing and mosaic were conducted using ENVI4.3 software. Mosaic was conducted because a single scene did not cover the whole study area. The mosaic scene was clipped using shape file of the study area with use of ENVI4.3. Finally, DEM file converted to IDRSI file format. Additionally, the slope factor calculated from DEM layer with use of IDRSI software (Figure 2). The road and river data were clipped from the data set of Ethio-GIS using ArcMap GIS 10 while settlement data of each village was accessed from GIS data base of Farm Africa -SOS Sahel Ethiopia, Bale REDD+ project (Figure 2). Those three layers imported to IDRSI file format and rasterized. Subsequently, distance from road, river and settlement were separately calculated using IDRS Software. The soil type layer was clipped from the Ethio-GIS database and imported to the IDRSI file format and rasterized to make suitable for deforestation modeling (Figure 2).
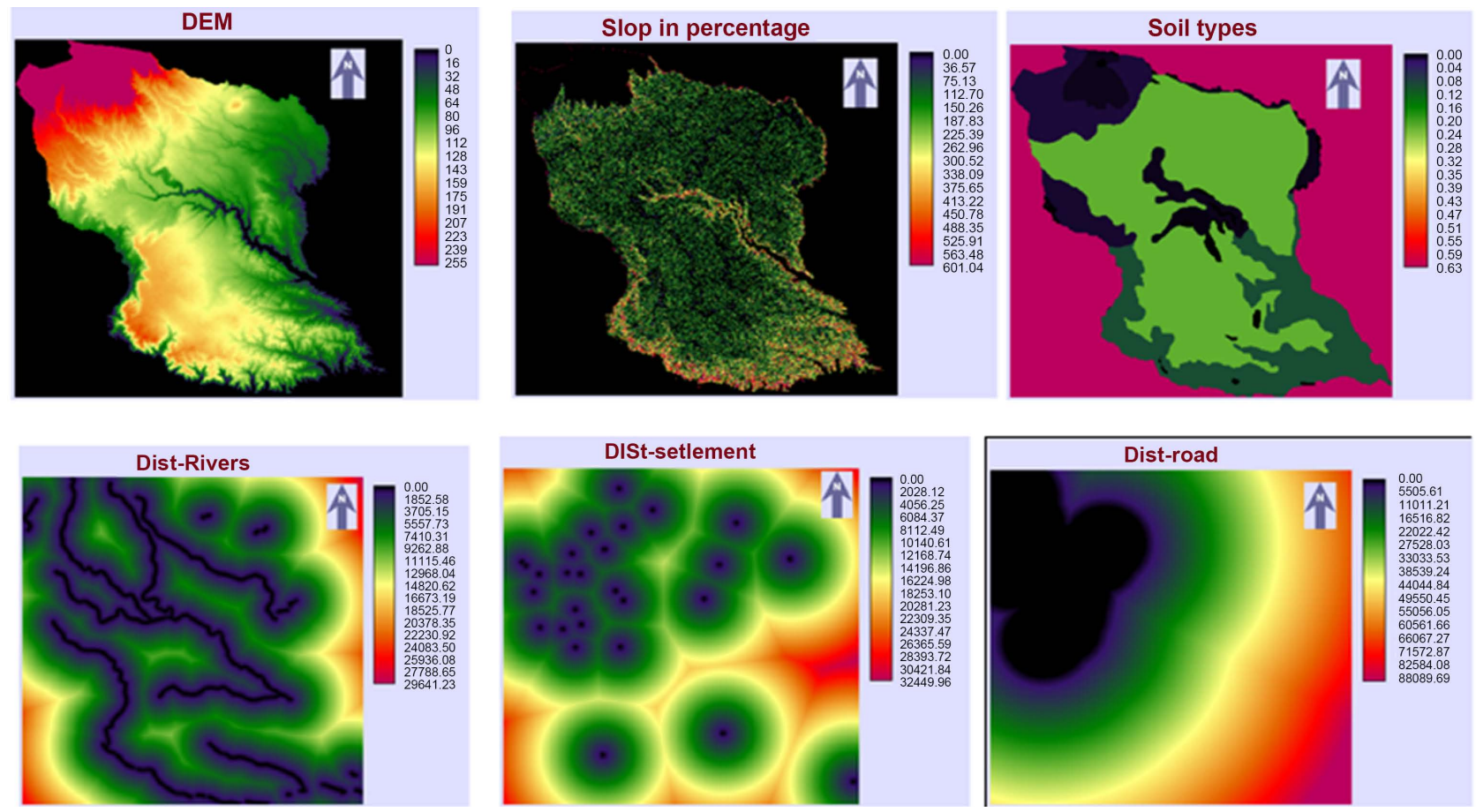

Figure 2. Layers of drivers of deforestation. Source: Own processed from Ethio-GIS data. 


\subsubsection{Testing Power of Deriving Variables}

The Cramer's V statistics employed to calculate the powers of all six factors with the use of IDRSI software. Cramer's V statistics is correlation coefficient that ranges from zero to one [11] [46]. The value greater than 0.15 is considered as acceptable while value greater than 0.40 is more accept for modeling [46] [51]. Prior to testing power of all variables in this study, layer of soil type linearized to continuous data using Evidence Likelihood because of its categorical data that could not be accessible to MLP algorithm. Powers of all six deriving variables were tested as indicated in Table 4. However, only three factors were considered such as DEM, Soil type and proximity to road based on v Cramer's statistics that exceed 0.40. These deriving factors are categorized as static and dynamics variables. Static variable is variable which is not changed over the time while the dynamic variable is time-dependent that continue to change over a time [52]. It is important to note that the dynamic variable requires updating in process of a modeling.

\subsubsection{Transition Potential Mapping}

Transition potential maps use to estimate susceptibility of the pixels from one class to other by influence of deriving factors [42] [46]. The transition potential map for each pixel contains probability value that ranges from zero to one whereas a large value indicates high rate of vulnerabilities [11] [49]. Transitional potential maps from a forest to farmland, shrubs and settlement were produced for this study purpose. These transitions maps produced based on the land-cover maps of 2000 and 2010 along various factors like road, DEM and soil type using multilayer perception algorithm. This conducted achieving an accuracy of $89.16 \%$ with RMS value of 0.28 while a default value of 10,000 iterations completed for both training and testing. In general, accuracy of around $80 \%$ is acceptable in predication of LULC [43] [51].

Multilayer perception is preferred because of its capability of modeling more than one transition at time and transforming categorical data to continuous data [46] [53]. Multilayer perception algorithm trains two sets of classes allocating $50 \%$ of samples for training and $50 \%$ to test the model. Accordingly, it trains pixels that have undergone transitions from first land category to the next classes.

Table 4. Cramer's V statistics of driving factors.

\begin{tabular}{cccc}
\hline Variables & Cramer's V coefficient & P value & Data nature \\
\hline Elevation & 0.58 & 0.00 & Static \\
Slope & 0.16 & 0.00 & Static \\
DIST-road & 0.45 & 0.00 & Dynamic \\
DIST-river & 0.28 & 0.00 & Dynamic \\
DIST-settlement & 0.22 & 0.00 & Dynamic \\
Soil type & 0.54 & 0.00 & Dynamic \\
\hline
\end{tabular}

Source: extracted data analysis. 
Secondly, it trains set of pixels that persisted from a first time to the next without change. This algorithm adjusts a model parameters through repeated iteration for training and testing until stopping criterion is satisfied in which the RMS error decreases as weight adjusted and accuracy rate increases [53] [54].

\subsubsection{Deforestation Prediction}

Deforestation predictions in this study were conducted for 2015 and 2030 based on transition potentials maps and Markov chain transition probability. Prediction for 2015 conducted for the purpose of model validation while a prediction of 2030 was conducted for purpose of analyzing a future scenario. Markov chain transition probability is used to generate probability that helps to predict future scenario based on LULC maps of two periods [50] [55] [56].

Land change modular provides predictions maps of hard and soft predictions. The hard prediction yields a projected map at a certain year in which each pixel is assigned to a certain land class [46] [49]. The soft prediction model uses to indicate vulnerability map in which each pixel is assigned a value from zero to one [49] [51] [53]. Probability value with lower value refers to less vulnerability while the higher value indicates high vulnerability to the change [11] [49].

\subsubsection{Model Validation}

Model validation is required to assess predictive ability of a model to predict what would happen in future [50]. It can be conducted comparing a projected map with a reference map [57]. Model validation for this study purpose was conducted by comparing the predicted map of 2015 with actually classified map of 2015 using IDRSI software. In the process, the actual map of 2015 was used as the reference map while a simulated map served as a comparison. The validation results are usually expressed in terms of Kappa indices which show agreement and disagreement in quantity and location between pair of two categorical maps [47] [58].

\subsection{Qualitative Data Collection Method and Analysis}

Identification of patterns of land-cover changes and a reason behind those changes commonly gathered using a focus group discussions, key informant interview and techniques of Participatory Rural Appraisal [59]. Key informant interviews were conducted in this study with 10 individuals who assumed having better knowledge about causes of deforestation and associated impacts.

In addition to this, a problem tree analysis technique employed to collect similar data. the selected sample sites were Burkitu, Nanigaadhera and Baraqvelleges commonly known as kebeles. These kebeles were selected from different agro ecological zone to capture people's perception. The kebeles were selected in consulting technical staff who were working at the district level. Six PRA data collection exercises were decided as sufficient and conducted having two exercises at each kebele. The participants assumed having better understanding about deforestation dynamic at each kebele. The selection of those participants 
was done by executive committee of respective kebele administrations and development workers. The size of participants in each group was 10 individuals with five males and five females. This is closer to a sample size of six to eight individuals suggested by [60].

During data collection process with each group, deforestation was identified as core problem and written on a card that produced for this purpose. In relation to identified deforestation, causes of deforestation and associated impacts were listed by participants. Cause and effect of deforestation were separately written on different pieces of cards and used to draw diagram on a ground that reflected relationship between causes, problem and impacts. Subsequently major causes and impacts of deforestation separately arranged by participants and ranked in decreasing order of their severity. Ranks that were given by each of six PRA groups were added together and presented in tabular forms. Moreover, qualitative data collected from key informant interviews and PRA technique used to develop thematic topics in which detail narration was done.

\section{Results and Discussion}

\subsection{Land-Use Land-Cover Classification in Year 2000, 2010 and 2015}

Land-use land-cover classification map is presented in Figure 3 which indicates that in year 2000 a shrub land accounts for $30 \%$ of a total area of the District. It

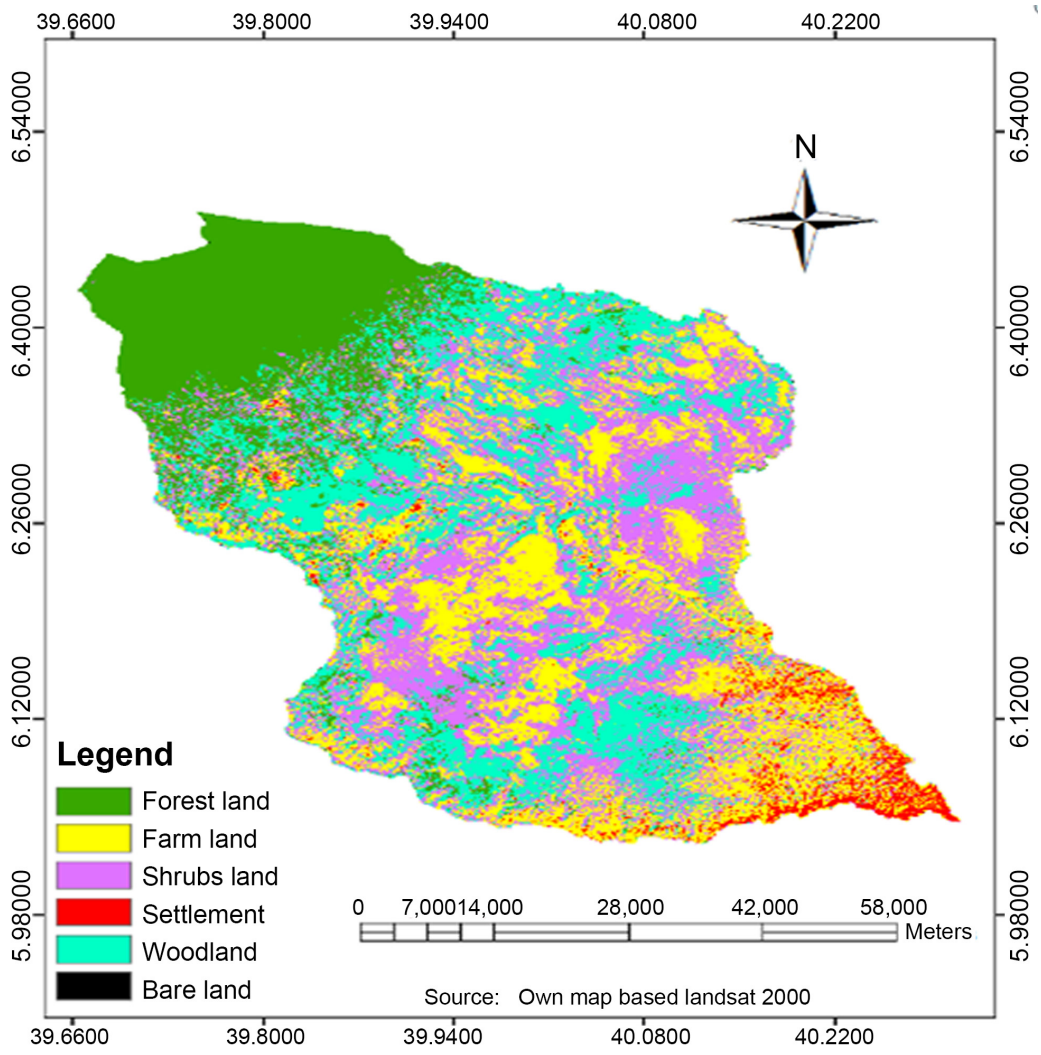

Figure 3. LULC 2000. 
was the largest proportion of land cover in year 2000. Farmland occupies the second place with $23 \%$ while the woodland comprises about $22 \%$. The forest class consisted $19 \%$ of the total area and followed by the bare-land and settlement which account for a proportion of $4 \%$ and $2 \%$, respectively (Table 5).

LULC map of year 2010 is presented in Figure 4. It revealed that a proportion of the farmland increased to $37 \%$ against the proportion of $23 \%$ in year 2000 . Similarly, a proportion of settlement increased by $2 \%$ against observed proportion of $2 \%$ in year 2000. In contrary, proportions of a bush land, forest and woodland were declined by $3 \%, 4 \%$ and $9 \%$, respectively.

In year 2015, the proportion of the farmland coverage was increased to $50 \%$ while proportion of shrubs land reduced to $19 \%$. The proportion of the forest

Table 5. Land-use land-cove of Delo Mena District.

\begin{tabular}{ccccccc}
\hline \multirow{2}{*}{ Classes } & \multicolumn{2}{c}{2000} & \multicolumn{2}{c}{2010} & \multicolumn{2}{c}{2015} \\
\cline { 2 - 6 } & Ha & $\%$ & Ha & $\%$ & Ha & $\%$ \\
\hline Forest & 91,339 & $19 \%$ & 73,274 & $15 \%$ & 70,481 & $15 \%$ \\
Farmland & 111,610 & $23 \%$ & 181,130 & $37 \%$ & 243,975 & $50 \%$ \\
Shrub & 145,656 & $30 \%$ & 130,529 & $27 \%$ & 90,657 & $19 \%$ \\
Settlement & 11,954 & $2 \%$ & 17,415 & $4 \%$ & 19,370 & $4 \%$ \\
Woodland & 105,730 & $22 \%$ & 63,962 & $13 \%$ & 41,044 & $8 \%$ \\
Bare land & 17,047 & $4 \%$ & 17,026 & $4 \%$ & 17,808 & $4 \%$ \\
Total & 483,335 & $100 \%$ & 483,335 & $100 \%$ & 483,335 & $100 \%$ \\
\hline
\end{tabular}

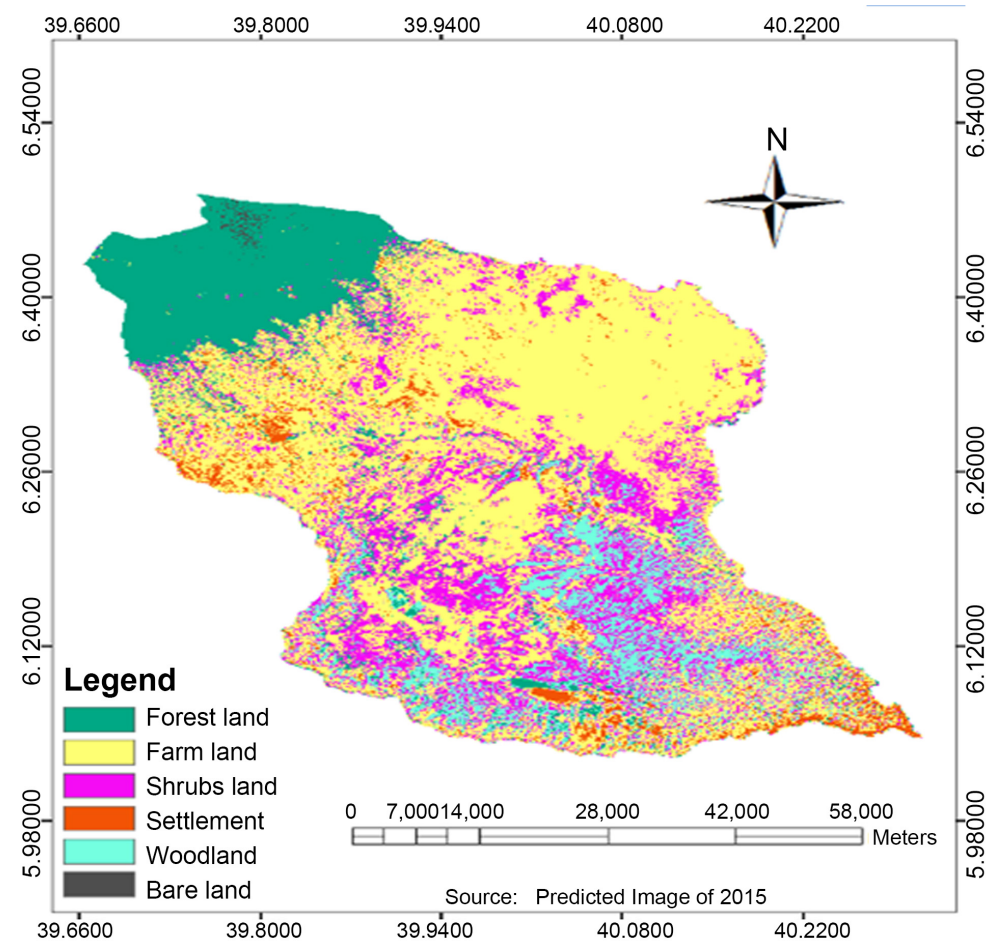

Figure 4. LULC 2010. 
and woodland in 2015 declined to $15 \%$ and $8 \%$, respectively against the proportions that indicated in year 2010 (Table 5). The share of a settlement and bare land remained constant with proportion of $4 \%$ for each class.

In terms of relative proportions, a forest class occupied $15 \%$ of the total area which was same as to that of 2010. However, it did not mean that the area of the forest class was same in both periods. For instance, the proportion of forest class in 2010 was 73,274 ha while in 2015 it was declined to 70,481 ha. Additionally, it was noted that a proportion of each land class was same as that of year 2010. For instance, a farm land occupied the first proportion in year 2010 by a relative proportion of $37 \%$ and continued first in year 2015 with the proportion of $50 \%$. Maps of LULC of 2000, 2010 and 2015 have also shown consistence increase in agriculture and settlement while it was reverse for the other LULC types (Figures 3-5).

\subsection{Land-Use Land-Cover Classification Accuracy Assessment}

Image classification contains some sort of errors which may happen in relation to classification process and satellite data acquiring processes that necessities accuracy assessment [15] [38]. Accuracy assessment in this study revealed kappa coefficient of $91 \%, 98 \%$ and $99 \%$ for 2000, 2010 and 2015, respectively. The overall accuracies of $83 \%, 96 \%$ and $100 \%$ were calculated for 2000, 2010 and 2015 , respectively. This implies that all classifications are in acceptable range

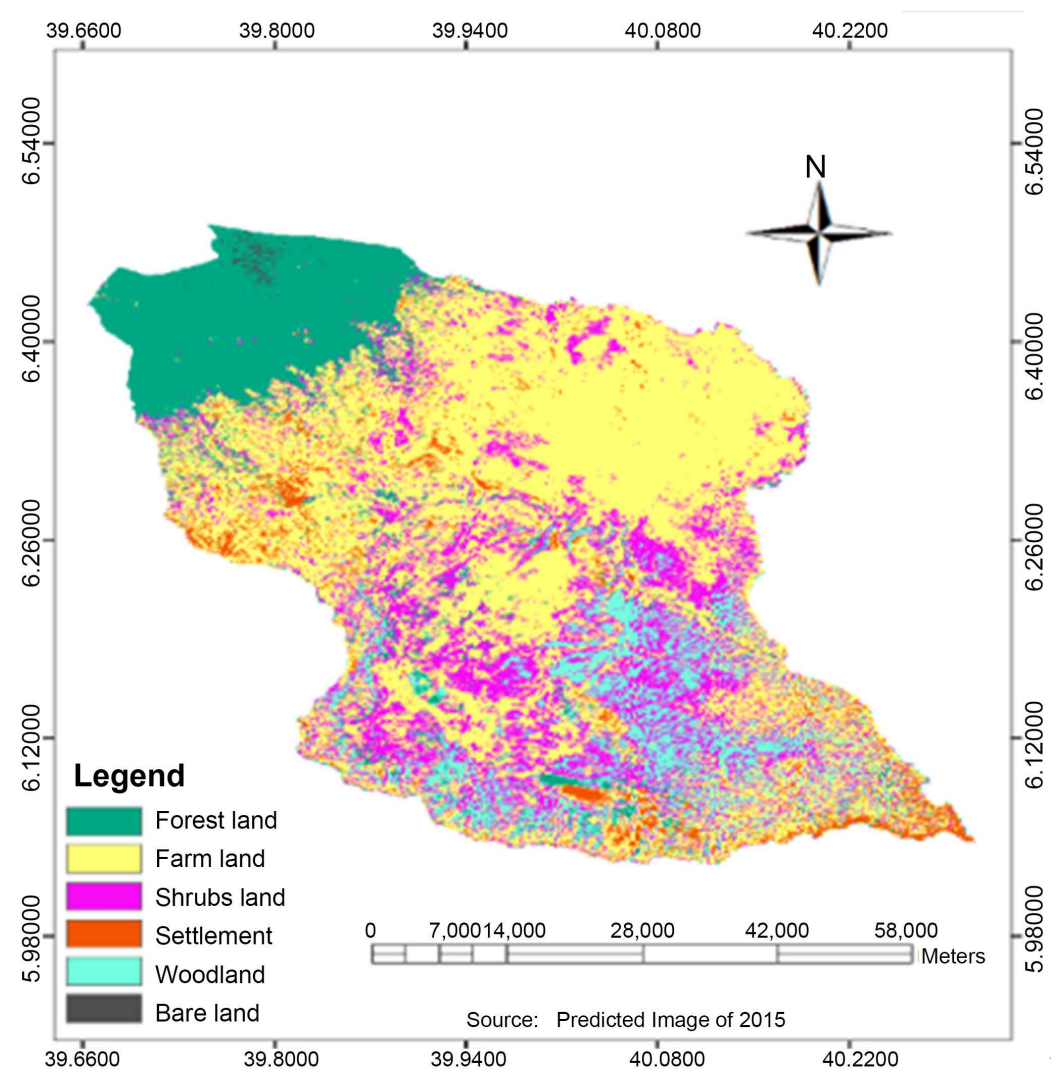

Figure 5. LULC 2015. 
because a kappa value of each is greater than $80 \%$ is an indicator for a strong accuracy [38].

\subsection{Extent and Annual Rate of Changes in Land-Uses Land-Covers}

Changes detection analysis was conducted for two different periods' between 2000 and 2010 and 2010 and 2015. Over the period of 2000 and 2010 a forest area lost by $20 \%$ at decreasing rate of $2 \%$ /year while between 2010 and 2015 a forest area was lost by $4 \%$ with the annual rate of $1 \%$ (Table 6 ). These rates of deforestation found greater than a rate of deforestation of $0.25 \%$ which detected for same place between 1986 and 2006 [61]. This implied that a rate of deforestation was increasing along temporal scale. The recorded rates of deforestation in this study were higher than a global rate of deforestation which was $0.4 \%$ and $1 \%$ for the same periods, respective. However, it was lower as compared to deforestation rates of the south and eastern African's countries which was 9\% between 2000 and 2010 and $3 \%$ between 2010 and 2015 [62] [63].

The area of farmland increased by $62 \%$ at annual rate of $6 \%$ during 2000 and 2010. Similarly, farmland continued to increase by 35\% between 2010 and 2015 with annual rate of $7 \%$ (Table 6). This annual rate of farmland increase was higher than rate of $1.71 \%$ which was recorded between 1973 and 1987 in the Bale Mountains Eco-region. However, it was lower as compared to annual rate of 9.34\% that occurred between 2000 and 2008 [38]. The woodland area was lost its area by $39 \%$ at annual rate of $4 \%$ during the first period. In the second period the woodland was lost by $36 \%$ at annual rate of $7 \%$. The annual loss to the shrubs land was $1 \%$ between 2000 and 2010 while $6 \%$ annual loss was recorded during the second period. The settlement area was increased by $5 \%$ and $2 \%$ during the first and second periods, respectively. On the other hand, the annual increasing rate of the bare land remained constant with $1 \%$ in both periods.

\subsection{Land-Use Land-Cover Losses, Gains and Net Changes}

Transition of land-use land-cover was analyzed for two periods. The first period

Table 6. Land-use land-cover dynamics of Delo Mena District.

\begin{tabular}{|c|c|c|c|c|c|c|c|c|c|}
\hline \multirow{3}{*}{ LLUC } & & & & \multicolumn{6}{|c|}{ Magnitude of changes } \\
\hline & \multicolumn{3}{|c|}{ Areas in ha } & \multicolumn{3}{|c|}{$2000-2010$} & \multicolumn{3}{|c|}{$2010-2015$} \\
\hline & 2000 & 2010 & 2015 & $\mathrm{Ha}$ & $\%$ & Rate/yr \% & $\mathrm{Ha}$ & $\%$ & Rate/yr \% \\
\hline Forest & 91,549 & 73,274 & 70,481 & $-18,275$ & $-20 \%$ & $-2 \%$ & -2793 & $-4 \%$ & $-1 \%$ \\
\hline Farmland & 111,607 & 181,130 & 243,975 & 69,523 & $62 \%$ & $6 \%$ & 62,845 & $35 \%$ & $7 \%$ \\
\hline Shrub & 145,611 & 130,529 & 90,657 & $-15,082$ & $-10 \%$ & $-1 \%$ & $-39,872$ & $-31 \%$ & $-6 \%$ \\
\hline Settlement & 11,954 & 17,415 & 19,370 & 5461 & $46 \%$ & $5 \%$ & 1955 & $11 \%$ & $2 \%$ \\
\hline Woodland & 105,693 & 63,962 & 41,044 & $-41,731$ & $-39 \%$ & $-4 \%$ & $-22,918$ & $-36 \%$ & $-7 \%$ \\
\hline Bare land & 16,922 & 17,026 & 17,808 & 104 & $1 \%$ & $0 \%$ & 782 & $5 \%$ & $1 \%$ \\
\hline Total & 483,335 & 483,335 & 483,335 & & & & & & \\
\hline
\end{tabular}


analysis included transition that occurred between 2000 and 2010. The second period transition included transitions happened between 2010 and 2015. Between 2000 and 2010, the analysis showed that the forest area was lost by 24,187 and gained by 5912 ha which resulted in the net loss of 18,275 ha. During 2010 and 2015 , a forest loss of 13,422 ha and gain of 10,629 ha detected with a net loss of 2793 ha. Similarly, during the first period, the woodland area was lost by 69,350 ha and gained 27,619 ha with the net loss of 41,731 ha. In the second period, 54,704 ha of woodland lost while a gain was 31,786 ha. This implied that wood land was lost by a net change of 22,918 ha (Figure 6).

A loss in shrubs land was detected as 84,625 ha while gain was 69,497 with a net loss of 15,128 ha. During the second period, a shrub land was lost by 97,312 ha and gained 57,441 hectors with net loss of 39,872 ha. In contrary, a farm land area was lost by 23,009 ha and gained 92,529 ha that resulted in a net gain of 69,520 ha between the period of 2000 and 2010. Between 2010 and 2015, a farmland lost 58,822 ha of its area and gained 121,668 ha with a net gain of 62,848 ha (Figure 6). Between 2000 and 2010, a settlement gained 7445 ha and lost 1984 ha which resulted in the net gain of 5461 ha. During the second period, a loss of 9245 ha and gain of 11,201 ha was detected with the net gain of 1955 ha. Regarding a bare land, significant transition was not detected (Figure 6).

\subsection{Spatiotemporal Dynamic Maps of Different Land-Cover Classes}

Contribution to Net Change in a Forest Class

A net forest loss of 18,725 ha was detected between 2000 and 2010 (Table 6). This net loss in a forest class contributed to an increase of other land-cover classes. Accordingly, 8965 ha of the forest area was converted to a farmland that
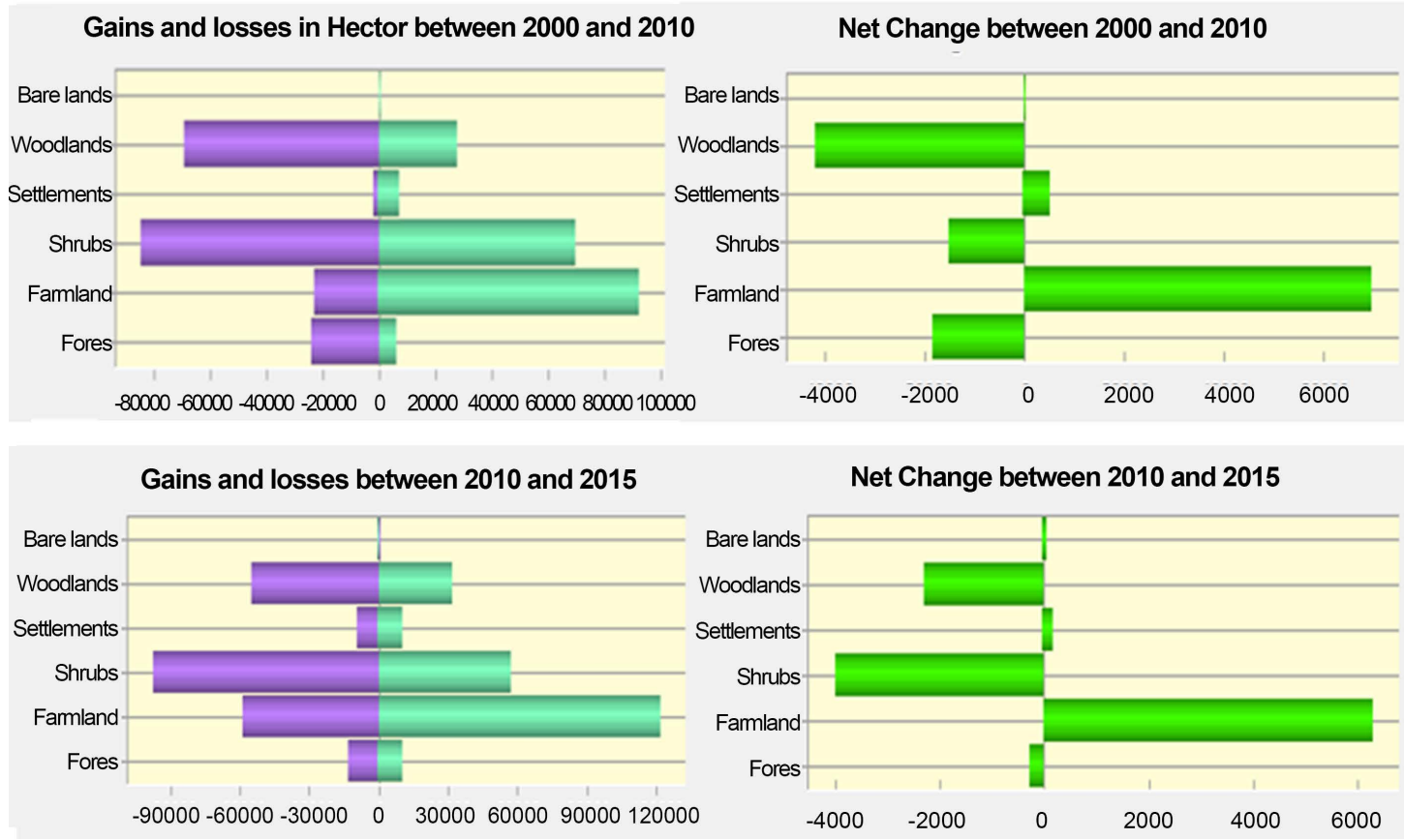

Figure 6. Gains, losses and net change between different periods. 
implied for an increase of the farm land by $8.03 \%$. Correspondingly, 7340 and 1702 ha of a forest areas converted to shrubs and wood lands that implied for area an increase of those land cover by $5.04 \%$ and $1.63 \%$, respectively. Additionally, 165 ha of a forest land was converted to increase settlement area by $1.38 \%$. Additionally, 103 ha of a forest area converted to a bare land that indicated an increase of bare land by $0.03 \%$ (Figure 7 ).

A net contribution of the forest resources was also analyzed for of 2010 and 2015. It revealed that a net forest loss of 2793 ha contributed to a change of other land-cover classes. Accordingly, 5011 ha of a forest area was converted to a farmland that implied for an increase of the farmland by $2.77 \%$. Similarly, 205 and 478 ha of forest areas converted to shrub and settlement that implied for increase of those land covers by $0.16 \%$ and $2.75 \%$, respectively. Furthermore, 779 ha of a forest area converted to a bare land that indicated an increase of $0.22 \%$. Contrarily, 3680 ha of a forest area was derived from the woodland which implied for decreasing in woodland by $5.75 \%$ (Figure 8 ).

As indicated on (Figure 9) many forest areas in a central part of Delo Mena District adjacent to a remaining forest area was largely converted to a farmland over a period of 2000 and 2010. A similar trend of conversion observed between 2010 and 2015 though trend of conversion to the farm land was sparsely occurred as compared to a previous period. The conversion of a forest to shrubs land observed around edge of existing forest at both periods. Similarly, between 2000 and 2010; the forest conversion to a wood land happened at southern edge of a forest area. However, a conversion to woodland was not indicated between 2010 and 2015. The expansion of settlement to a forest area observed between 2010 and 2015 (Figure 9).

During 2000 and 2010, the woodland forest converted to a farmland in northeast and southern parts of the District. At this period, a large spatial pattern in wood land was observed in the central and southern part of the district. Similar pattern of woodland conversion to farm land occurred during a period of 2010 and 2015. In both periods, the conversion of woodland to shrubs land was widely sparse across District (Figure 9). This analysis was substantiated by data collected

Contributions to Net Change in forest (in ha)

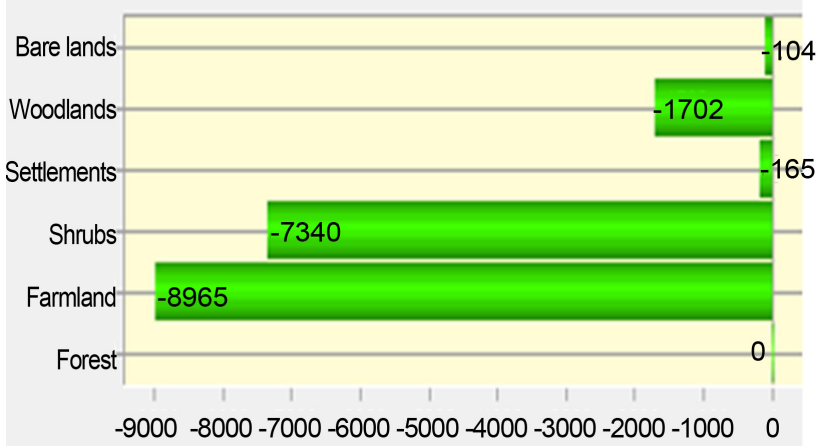

\section{Contributions to Net Change in forest (\% change)}

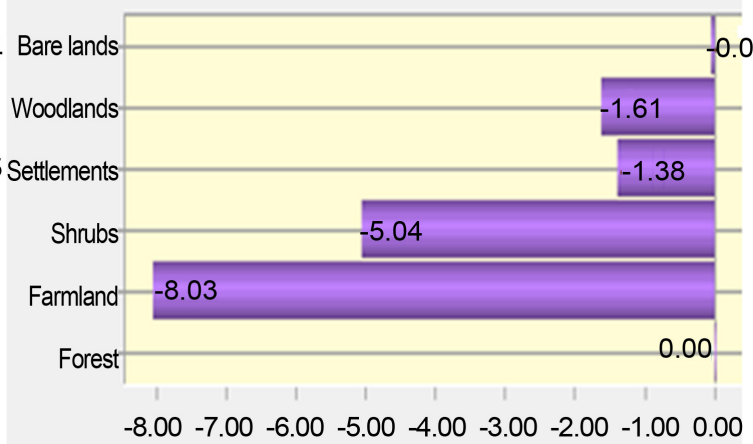

Figure 7. Contribution to net change in forest between 2000 \& 2010. 


\section{Contributions to Net Change in forest (in ha)}

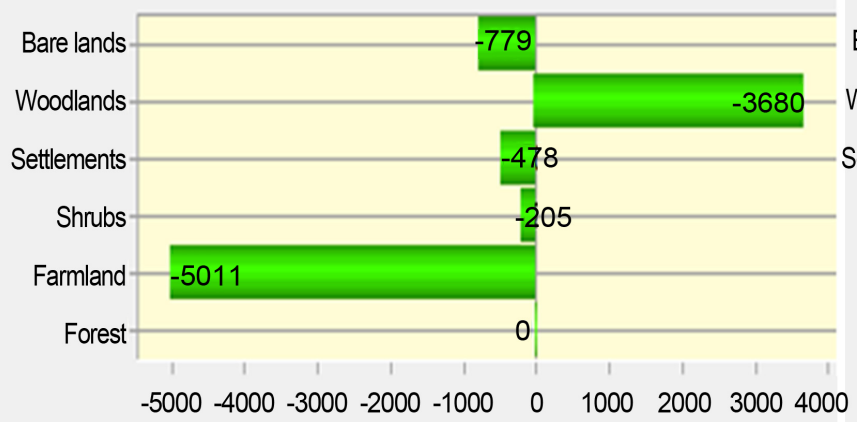

Contributions to Net Change in forest (\% change)

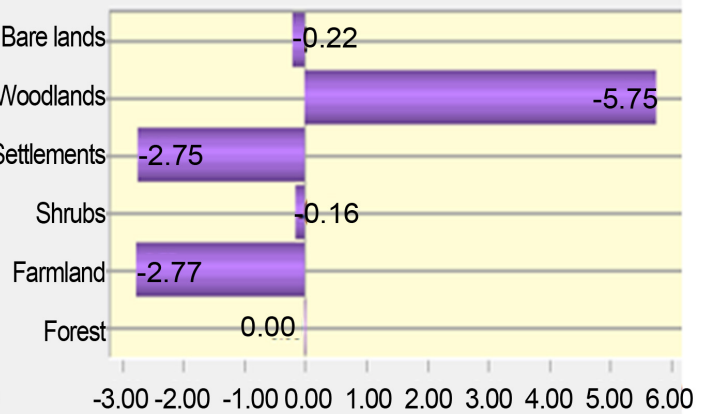

Figure 8. Contribution to net change in forest between 2010 \& 2015 .
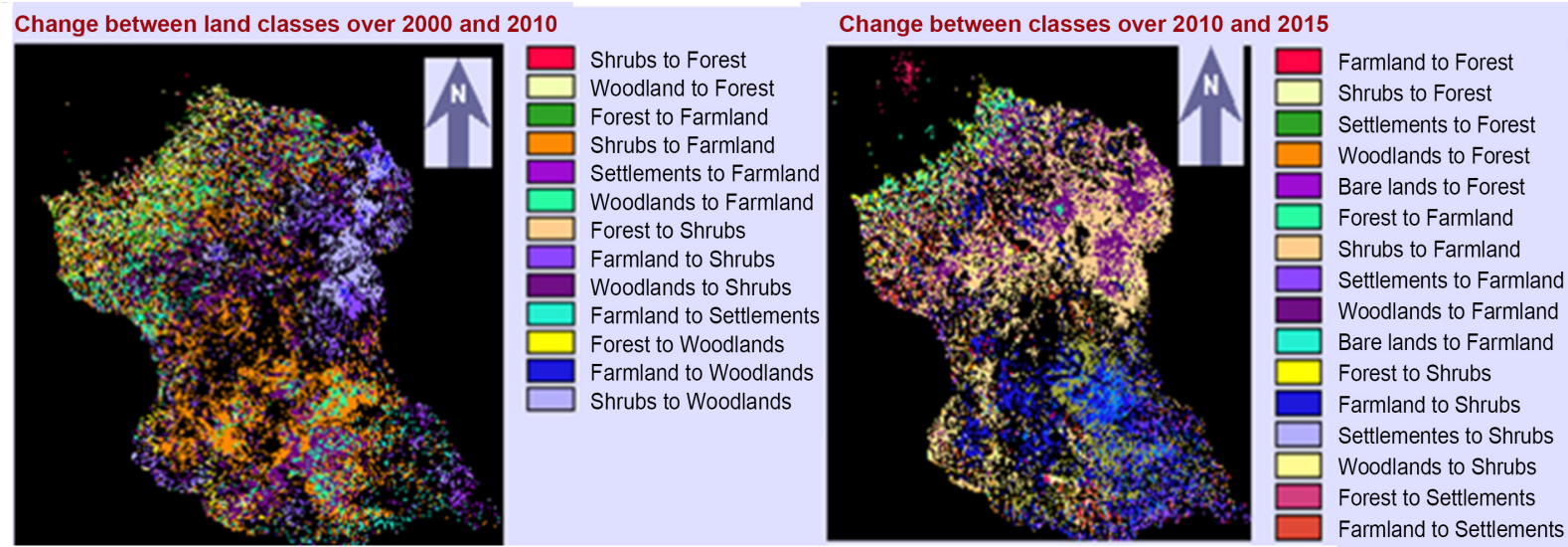

Figure 9. Land-use land-cover dynamics base on transition analysis.

through PRA technique and from key informant interview. Both data source confirmed that woodland areas mainly converted to production of sesame while forest converted to coffee plantation.

\subsection{Deforestation Prediction of Year 2030}

Future deforestation status at a study site for year 2030 was predicted using deriving variables like elevation, distance from roads and soil type (Figure10). This hard prediction indicates that by year 2030 about 33,243 ha of forest area will be expected to disappear. This implies that by 2030 the forest area e declines by $45 \%$ at annual deforestation rate of $2 \%$ between 2010 and 2030 (Table 7). Similarly, the woodland area is predicted that it will be increased by $10 \%$ in year 2030 at annual rate of $1 \%$. The area of shrubland and farmland are predicted to increase by $8 \%$ for each class. In the meantime, the area of settlement will increase by $4 \%$ while ta bare land decreases by $12 \%$ at annual rate of $1 \%$ (Table 7).

This forest loss of 33,243 ha in 2030 would accounts about $0.4 \%$ of $9,000,000$ ha of a deforestation predicted to happen in Ethiopia between 2010 and 2030 [64]. Moreover, this forest loss will have implication for climate change. For instance, if 33,243 ha of the forest area that is supposed to disappear is multiplied by $510 \mathrm{tCo}_{2} / \mathrm{ha}$ [23]; about 17,000,000 of carbon dioxide will emit to atmosphere. 
Table 7. Dynamics of deforestation from initial date of predictions.

\begin{tabular}{cccccc}
\hline LULC & 2010 & 2030 & Area change in ha & Change in \% & Annual change in \% \\
\hline Forest & 73,274 & 40,031 & $-33,243$ & $-45 \%$ & $-2 \%$ \\
Farmland & 181,130 & 196,119 & 14,989 & $8 \%$ & $0 \%$ \\
Shrub & 130,529 & 141,534 & 11,005 & $8 \%$ & $0 \%$ \\
Settlement & 17,415 & 18,083 & 668 & $4 \%$ & $0 \%$ \\
Woodland & 63,962 & 70,542 & 6580 & $10 \%$ & $1 \%$ \\
Bare land & 17,026 & 14,996 & -2030 & $-12 \%$ & $-1 \%$ \\
Total & 483,335 & 481,305 & & &
\end{tabular}

Source: From own analysis.

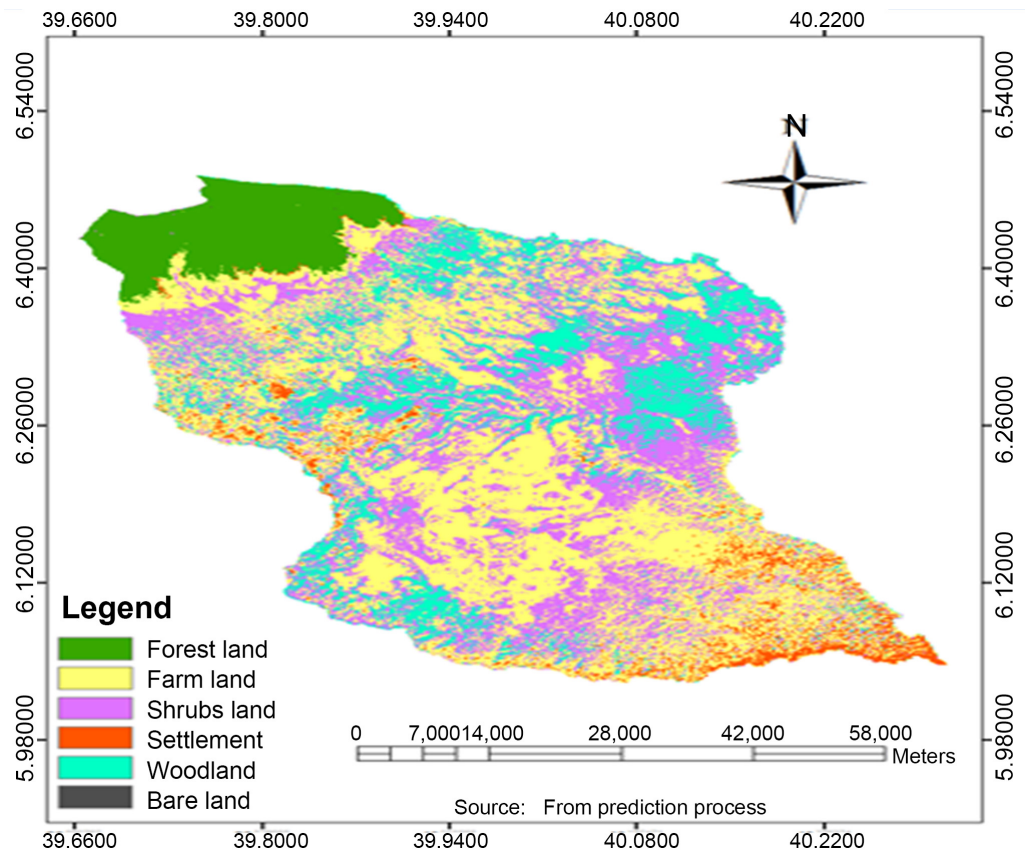

Figure 10. Hard predictions of deforestation in 2030.

In terms of monetary value, it would imply for a loss of UDS $85,000,000$ at the rate of 5 USD per ton of carbon dioxide equivalent.

With respect to a predicted forest losses of 33,243 ha was further analyzed to investigate by how much a forest area will be expected to convert to other different land-use land-cover classes. The analysis indicated that by year 2030 about 14,955 ha $(8.25 \%)$ of the forest land will change to a farmland. Additional, 10, 984 ha $(8.41 \%)$ will be converted to a shrub land. Similarly, 6565 ha (10.26\%) and 667 ha $(3.83 \%)$ will be changed to woodland and settlement lands, respectively (Figure 11).

\subsection{Forest Vulnerability Prediction in Year 2030}

The vulnerability of a forest to deforestation is produced by the soft prediction model in which each pixel is assigned to a value from zero to one that indicates 
Contributions to Net Change in Forest in ha by 2030

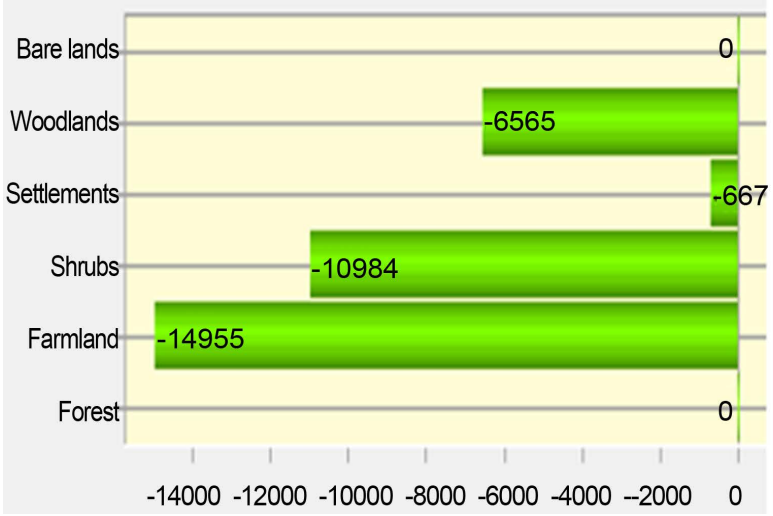

Contributions to Net Change in Forest ( $\%$ change) by 2030

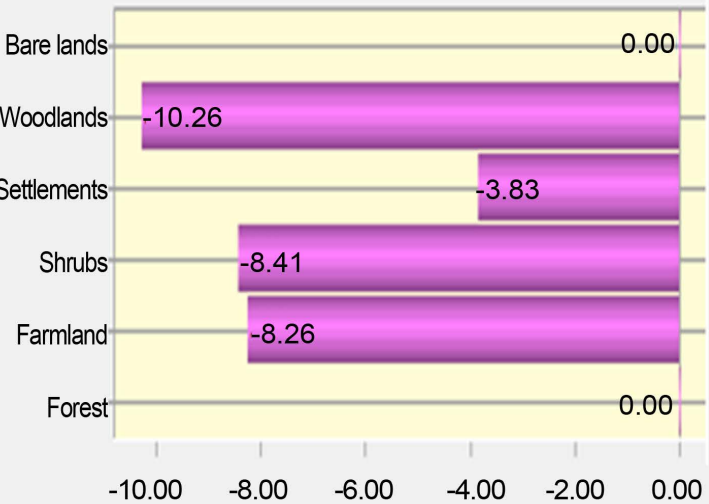

Figure 11. Net forest contribution b/n 2010 and 2030 based on own analysis.

probability of change [46] [53]. A large value indicates high forest vulnerability to deforestation while those smaller numbers indicates a lower vulnerability. The value indicated in red and yellow colors on (Figure 12) shows a high vulnerability of a forest to other land classes. In contrary, blue and green colors indicated a lower vulnerability to change. This predicted map indicated that there would be high possibility of deforestation around edge of existing forest.

\subsection{Model Validation}

Model validation measures accuracy of a model to know by how much a prediction is certain to predict what would be expected to happen [57]. A model validation in this study was conducted by comparing predicted map of 2015 with actual map of 2015. The result indicated that a deforestation model was confident to predict future deforestation with accuracy of $80 \%$. Overall accuracy of equal or greater than $80 \%$ is acceptable [43]. In addition to overall accuracy, the validation indicated that a largest component of agreement between the two maps was found due to location which was $78 \%$. The agreement due to quantity was $58 \%$. This implied that prediction of a location is more accurate than predicting a quantity. In contrary, disagreement in quantity found lower than a disagreement in location that implies the model predicted the quantity than location.

\subsection{Causes of Deforestation and Associate Impacts in the Study Area}

Understanding the reasons behind deforestation is a critical need to scientists and land managers because it helps to take appropriate measure [59]. This study attempted to investigate causes and impacts of deforestation. Participants of PRA of different groups identified deforestation as the core problem. Subsequently, proximity and underlying causes of deforestation were identified including impacts of deforestation as it is depicted in Figure 13.

In the center of the diagram, deforestation was indicated as a core problem. At 


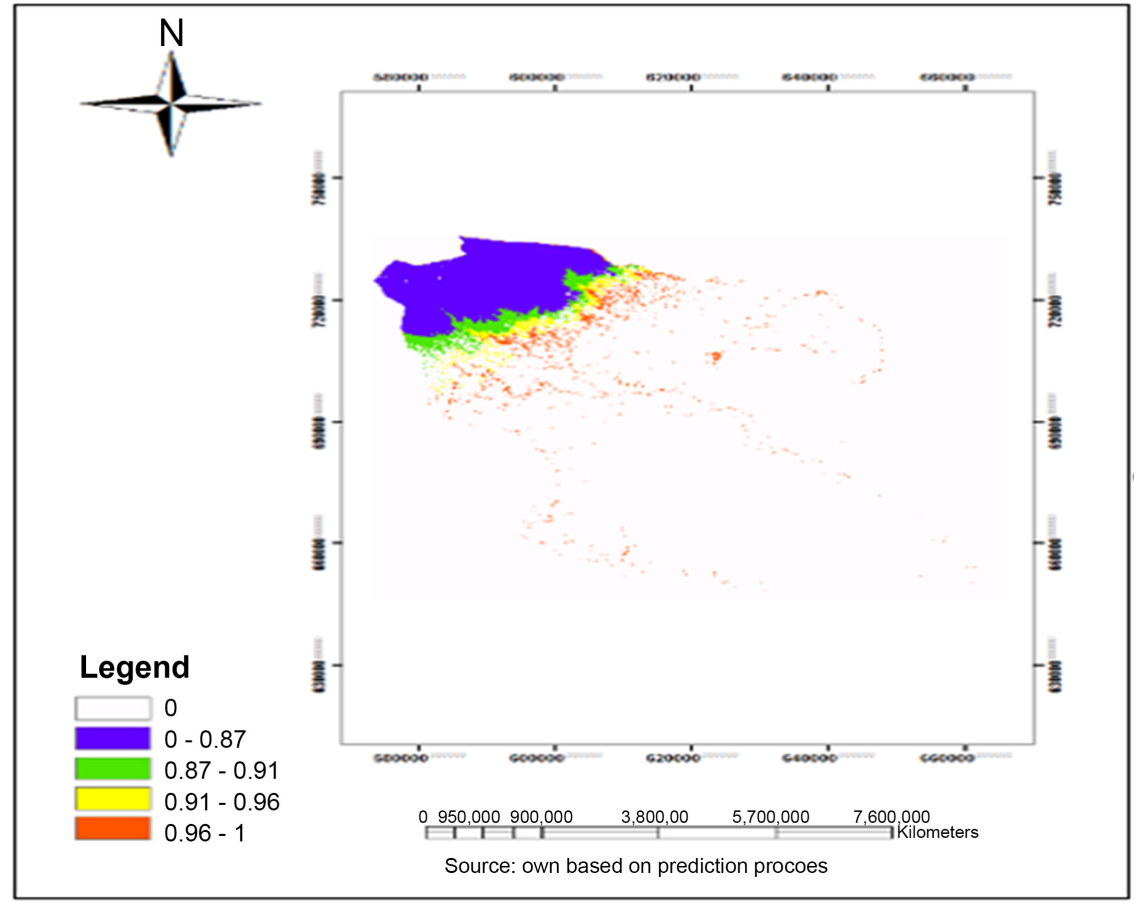

Figure 12. Soft prediction map of deforestation in 2030.

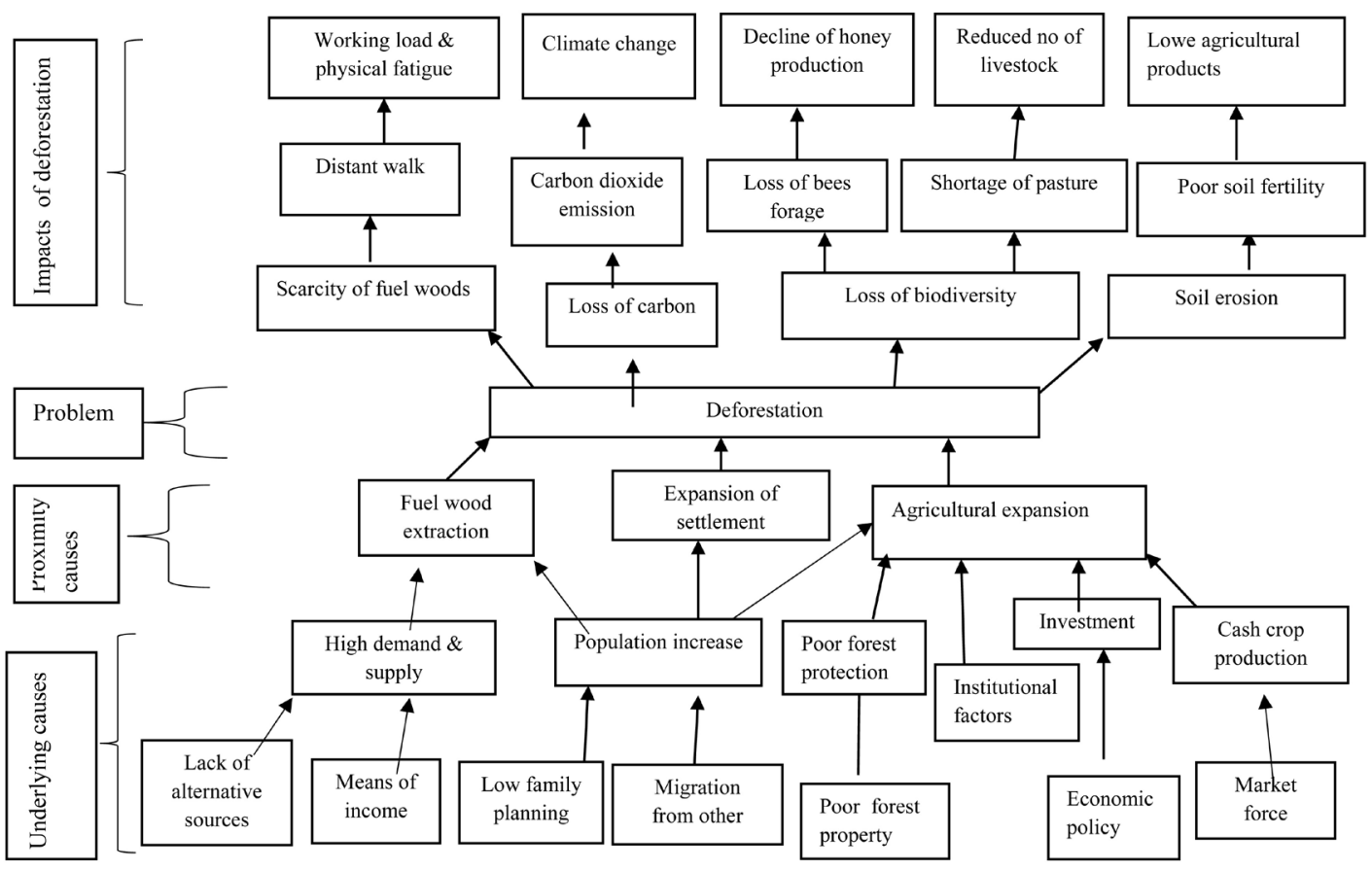

Figure 13. Diagram of Problem Tree Analysis developed during PRA exercise in the field.

its immediate lower part, agriculture expansion, settlement increase and fuelwoods extraction were identified as proximate causes of deforestation. A population increase, policy factors and institutional factors were altogether identified as underlying forces that led to happing of proximity causes of deforestation. Lastly it was observed that a deforestation resulted in different impacts like a scarcity 
all necessary elements.

\subsubsection{Proximity Causes of Deforestation}

Proximate causes are immediate human activities at a local level that directly cause deforestation or land-cover change [65] [66] [67]. At the global scale, agricultural expansion, wood extraction and expansion of an infrastructure were identified as the main proximity causes of deforestation [65]. Likewise, in this study proximity derivers were identified as farmland expansion, fuel wood extraction, settlement increase and investment land expansion.

About $52 \%$ of total 60 PRA's participants responded that agriculture expansion was the major cause of deforestation in the case of Delo Mena district (Table 8). This finding strongly supports to the remote sensing analysis that reveals that a farmland increased by $62 \%$ between 2000 and 2010 while it increased by $35 \%$ between 2010 and 2015 (Table 6). This study finding provides empirical evidence to theoretical argument that explains agricultural expansion is the most direct driver of land-cover at the global scale [67]. On the other hand, settlement expansion was perceived as proximity cause of deforestation by $18 \%$ of PRA's participant. Key informants added that inline to a population increase individuals were clearing the forest and woodland areas to establish own settlements that resulted in spontaneous deforestation. This supported to argument of [23] that explained a rapid population growth resulted in expansion of a farmland and settlements that threaten high conservation values of the area.

In this study area, expansion of the investment land identified as cause of deforestation by $13 \%$ of PRA's participants (Table 9). The participants of PRA explained that many forestlands areas converted to agricultural land by investors particularly in Baraq, kelegolba and Nanga-dherakebeles. However, key informants

Table 8. The underlying causes of deforestation.

\begin{tabular}{|c|c|c|c|c|c|c|c|c|c|c|c|c|c|c|c|}
\hline \multirow{4}{*}{$\begin{array}{c}\text { Underlying } \\
\text { forces }\end{array}$} & \multicolumn{12}{|c|}{ Scores given by different PRA group in different kebeles } & \multirow{3}{*}{\multicolumn{2}{|c|}{$\begin{array}{l}\text { Sum of } \\
\text { scores }\end{array}$}} & \multirow{4}{*}{ Rank } \\
\hline & \multicolumn{4}{|c|}{ Burkitu } & \multicolumn{4}{|c|}{ Nanigadhera } & \multicolumn{4}{|c|}{ Beraq } & & & \\
\hline & \multicolumn{2}{|c|}{ Group1 } & \multicolumn{2}{|c|}{ Group 2} & \multicolumn{2}{|c|}{ Group 1} & \multicolumn{2}{|c|}{ Group 2} & \multicolumn{2}{|c|}{ Group 1} & \multicolumn{2}{|c|}{ Group 2} & & & \\
\hline & \# & $\%$ & \# & $\%$ & \# & $\%$ & \# & $\%$ & \# & $\%$ & \# & $\%$ & \# & $\%$ & \\
\hline $\begin{array}{c}\text { Population } \\
\text { increase }\end{array}$ & 5 & 50 & 4 & 40 & 4 & 40 & 3 & 30 & 3 & 30 & 3 & 30 & 22 & 37 & 1 \\
\hline $\begin{array}{l}\text { Increased } \\
\text { fuelwoods } \\
\text { consumption }\end{array}$ & 1 & 10 & 1 & 10 & 2 & 20 & 2 & 20 & 2 & 10 & 1 & 10 & 9 & 15 & 3 \\
\hline $\begin{array}{l}\text { Economic \& } \\
\text { market forces }\end{array}$ & 0 & 0 & 1 & 10 & 0 & 0 & 3 & 30 & 2 & 20 & 2 & 20 & 8 & 13 & 4 \\
\hline $\begin{array}{l}\text { Propriety } \\
\text { rights issue }\end{array}$ & 2 & 20 & 2 & 20 & 3 & 30 & 2 & 20 & 2 & 20 & 4 & 40 & 15 & 25 & 2 \\
\hline $\begin{array}{l}\text { Institutional } \\
\text { factors }\end{array}$ & 2 & 20 & 2 & 20 & 1 & 10 & 0 & 0 & 1 & 10 & 0 & 0 & 6 & 10 & 5 \\
\hline Total & 10 & 100 & 10 & 100 & 10 & 100 & 10 & 100 & 10 & 100 & 10 & 100 & 60 & 100 & \\
\hline
\end{tabular}

Source: Summarized finding based on Participatory Rural Appraisal data. 
Table 9. Impacts of deforestation in case of Delo Mena district.

\begin{tabular}{|c|c|c|c|c|c|c|c|c|c|c|c|c|c|c|c|}
\hline \multirow{4}{*}{$\begin{array}{l}\text { Underlying forces } \\
\text { of deforestation }\end{array}$} & \multicolumn{12}{|c|}{ Scores given by different PRA groups in different kebeles } & \multirow{3}{*}{\multicolumn{2}{|c|}{$\begin{array}{l}\text { Sum of } \\
\text { scores }\end{array}$}} & \multirow{4}{*}{ Rank } \\
\hline & \multicolumn{4}{|c|}{ Burkitu } & \multicolumn{4}{|c|}{ Nanigadhera } & \multicolumn{4}{|c|}{ Beraq } & & & \\
\hline & \multicolumn{2}{|c|}{ Group 1} & \multicolumn{2}{|c|}{ Group 2} & \multicolumn{2}{|c|}{ Group 1} & \multicolumn{2}{|c|}{ Group 2} & \multicolumn{2}{|c|}{ Group 1} & \multicolumn{2}{|c|}{ Group 2} & & & \\
\hline & \# & $\%$ & \# & $\%$ & \# & $\%$ & \# & $\%$ & \# & $\%$ & \# & $\%$ & \# & $\%$ & \\
\hline Soil erosion & 1 & 10 & 1 & 10 & 2 & 20 & 2 & 20 & 3 & 30 & 3 & 30 & 12 & 20 & 3 \\
\hline Climate change & 1 & 10 & 0 & 0 & 2 & 20 & 1 & 10 & 2 & 20 & 3 & 30 & 8 & 13 & 4 \\
\hline $\begin{array}{c}\text { Loss of } \\
\text { biodiversity }\end{array}$ & 3 & 30 & 3 & 30 & 4 & 40 & 2 & 20 & 2 & 10 & 2 & 20 & 16 & 27 & 2 \\
\hline $\begin{array}{l}\text { Scarcity of } \\
\text { fuelwoods }\end{array}$ & 5 & 50 & 6 & 60 & 3 & 30 & 5 & 40 & 3 & 40 & 2 & 20 & 24 & 40 & 1 \\
\hline Total & 10 & 100 & 10 & 100 & 10 & 100 & 10 & 100 & 10 & 100 & 10 & 100 & 60 & 100 & \\
\hline
\end{tabular}

Source: Summary of scores from Participatory Rural Appraisal data.

argued that a proportion of forest area that was converted to investment land not significant as compared to expansion for subsistence farming. Besides this, $17 \%$ of PRA's participants perceived that fuelwoods consumption particularly charcoaling was identified as one of the main causes of forest degradation (Table 8).

Furthermore, PRA's participants explained that a charcoaling activity was commonly practiced in rural areas by poor people to generate their own incomes. This supports to argument that explains fuelwood and charcoal productions are not only source of energy but also serves as means of income generating [9]. The key informants explained that demand for charcoal in urban areas became increasing because of absence of alternative energy sources. Therefore, increasing demand for charcoal resulted in rising of price that attracted illegal charcoal traders to motivate rural people to produce more charcoals that continuously supplied to urban areas. In general, it was confirmed that there was an increasing consumption trend of fuelwood. This was strongly support to a prediction that made at national scale. The prediction indicated that a fuelwood increase by $65 \%$ between 2010 and 2030 that implied a forest degradation by removing more than 22 million tons of woody biomass [68]. In addition to this, the study finding supported to study finding of [69] that reported 15 to $29 \mathrm{~kg}$ of fuel-woods consumption in a week to produce meal of 13 to 26 adult. In the meantime, it was also reported that adoption of fuelwood saving stoves contributed to a reduction of fuelwood consumption by $28.6 \%$.

\subsubsection{Underlying Forces of Deforestation}

Underlying forces of deforestation are indirect factors that aggravate effects of proximity causes [67] [70]. In this study, the underlying derivers identified as demographic, economic, policy and institutional factors. Of the total PRA participants $37 \%$ perceived that population increase was the key underlying deriver of deforestation (Table 8). This supports to the Neo-Malthusians school of taught which argues that population increase results in environment destruction unlike 
optimistic taught of Boserupians that argues population growth helps to develop technological innovation which helps efficient utilization of resources [9]. The cause why population size was increasing explained by key interview informants and PRA's participants indicating that insufficient access to family planning and in coming of migrants from other places like from Harragae, Shawa and Gonder. According to [71], population of Delo Mena District in 2007 was 181,537 individuals and estimated to reach 219,297 in year 2015 at annual growth rate of $2.6 \%$. Therefore, comparing population of 2015 to the available farmland by 2015 (Table 5) implies that an average farm holding size will be $0.01 \mathrm{~km}^{2} /$ person. This indicted that there was shortage of a farmland that could not support farmers to produce sufficient yield.

In this study, a market force and demand for agricultural land investment identified as main economic factors that aggravated deforestation. Accordingly, $13 \%$ of PRA's participants perceived economic force was underlying causes of deforestation (Table 8). The key interview informants confirmed that a vegetation land was converted to a farmland for the production of cash crops like the sesame and coffee. This finding supports to a theoretical argument that explains higher market price for crops leads to an increase of deforestation [72]. This indicates that deforestation is not only occurred because of subsistence farming but it also occurs because of economic reason. Besides to this investment land expansion was indicated as one of underlying causes of deforestation. Key interview informants indicated that investment expansion particularly in the woodland areas created sever deforestation.

Many misdirected policies that poorly defined property right of forest resources led to loss of large forest areas in many developing countries which was ended up with tragedy of open access situation [65] [72]. The Tragedy of open refers to the condition in which resources do not belong to anyone where resources are indefinitely exploited [9]. In the study site, the key interview informants thoroughly explained that denial of forest customary rights put a forest under situation of open access where sever deforestation happened. This was happen because communities restrained themselves from a forest protection in light of losing a forest ownership right. On the other hand, though there was claim that a forest belong to a state, a government's machineries could not reach every place to make sure forest protection. Therefore, $25 \%$ of the PRA's participants responded that policy factor was one of underlying cause deforestation (Table 9).

The finding strongly supports to the finding of [73] that was reported before 1930s, the forest resource in the Delo Mena District was belong to local community and managed sustainably. Similarly, it was argued that in Ethiopia around 1980sa forest management arrangement overlooked needs and access rights to a forest [74]. In general, the finding supports to a conclusion in many countries the governments had nominal control of the forest control but were found weak in a forest protection [65] [72].

Apart this, the key informants interviews indicated that the Participatory For- 
est Management was introduced in 2007 by the Farm Africa and SOS Sehal Ethiopia. As it is witnessed by the key informants through PFM process, customary rights have restored in which rights and responsibilities are clearly defined that contributes to decline in a rate of deforestation. This was also confirmed in remote sense data analysis that indicated deforestation was reduced to $1 \%$ between 2010 and 2015 against a rate of $2 \%$ between 2000 and 2010 when PFM was not either initiated or at infant stage. The finding was strongly support to contribution of PFM that reported by [75] that argued a forest cover in Ethiopia was increased up to $15.6 \%$ between 2001 and 2006 in the PFM areas while decreasing up to $16 \%$ was detected in non PFM areas.

Institutional factors refer to a government's organizations that are responsible of law enforcement [65] [76]. Failure of institutions to deliver its responsibility can lead to deforestation. In this study, institutional factors perceived as underlying deriving forces of deforestation by $10 \%$ of PRA's participants (Table 8). The implications of this factor are explained by key informants. Accordingly, they explained the implications from two perspectives:

Primarily, it was explained that Office of Agriculture at the District level was encouraging farmers to expand their farmland size at the expense of a forest land and woodlands under a motive of ensuring food security. This was real, the paradox to a food security strategy of Ethiopia that launched in 1996 and revised in 2002 which paid attention to environmental rehabilitation and forestry management [77]. This clearly has revealed that how sectoral institution at grass root level contradicts with the national policy. Secondly, it was explained that a forestry sector that supposed to administer forest resource was less equipped in terms of manpower and logistic including frequent restructuring that undermined its efficiency. This view strongly supports to what was reported by [74] that explained the forestry institution was gone through frequent restructuring more than 20 years both at the Federal and Regional levels that undermined institutional efficiency that led to continuous deforestation.

\subsubsection{Socio-Economic and Environment Impacts of Deforestation}

Forest provides variety of social and economic benefits, ranging from easily quantified economic values to ecological services [78]. However, these services became under the pressure because of increasing trend of deforestation. In this study area, climate change, loss of biodiversity, soil erosion with poor soil fertility, scarcity of fuelwoods were identified as major impacts of deforestation based on perception of local community (Figure 13). About 20\% of the PRA's participants perceived that soil erosion and soil fertility loss mentioned as clear impacts of deforestation. The key informants explained that poor soil fertility caused by soil erosion resulted in low crop production and productivity which led to food insecurity.

Besides to this, $40 \%$ of PRA's participants perceived that scarcity of fuelwoods was the top impact of deforestation. Key informants indicated that location of remaining forests was become far away from settlement areas. Therefore, local 
community, particular women were obliged to walk a long distance to collect fuelwoods. This implied for more workload and physical exhaustion to women. The finding supported to argument of [79] that reported a women spent $3-7$ hours every week to collect fuel woods that let them to loss their productive time. Moreover, it was pointed out that a price of fire wood increased much and beyond the purchasing capacity of some low income section of the society.

In this study, 13\% of PRA's participants perceived that deforestation resulted in climate change (Table 9). The Key informants explained that they observed variability of climate elements such as shortage of rain fall and persisted drought that resulted in decline of agricultural production and productivity. The remote sense data analysis revealed that between 2000 and 2015 about 21,068 ha of forest converted to other land uses (Table 5). This implied for carbon dioxide emission of ten millions of tons at a rate of 510-ton carbon dioxide/ha that was estimated for moist forest of Bale Ecoregion [80]. In terms of monitory value, it implies for a loss of USD eighty five million, if a ton of carbon dioxide emission is supposed to sell for USD five per a ton.

The forest loss of 21,068 ha had a negative implication for biodiversity of a forest resource. Key informants explained that charcoal producers used to cut Acacia species and Combertumsps to produce charcoal which resulted in depletion of those preferred tree species. Additionally, it was explained that an expansion of agricultural investment resulted in a loss of plants species particularly in a lowland areas like at Beraqkebele. It was explained that investors converted woodland areas that used to serve as habitat of wildlife and pasture for cattle grazing. The loss of biodiversity which can be described in terms of loss of grasses and tree species has reduced its potential uses to feed cattle and bees' colony. This resulted in a low productivity of livestock and low production of forest honey including decreasing in the size of cattle holding. In light of all these, $27 \%$ of PRA's participants perceived that deforestation resulted in biodiversity loss (Table 9).

\section{Conclusion}

The result of land use land cover change indicated that the forest areas were 91,339, 73,274 and 70,481 hectors in year 2000, 2010 and 2015, respectively. This forest area was reduced by $20 \%$ between 2000 and 2010 at annual rate of $2 \%$. Between 2010 and 2015, a forest area was lost by $4 \%$ with annual rate of $1 \%$. However, it is commonly argued remote sensing data analysis has a limitation to explain non spatial data like derivers of deforestation. In this case study, it was indicated that remote sensing data indicated magnitude and spatial patterns of deforestation but failed to explain about causes and impacts of deforestation. This gap was addressed by qualitative data that were collected from a local community through various means. Therefore, it is important to notice that a remote sensing land change analysis needs to be complemented by qualitative data to provide a complete picture of the study area. Another important point is 
that deforestation is usually assumed to happen because of subsistence farming by poor people but it does not always hold true because of other factors. For instance, in this case study, it was found that high prices for cash crops like coffee and seaman motivated many people to engage in conversion of the forest lands to production of those cash crops.

Moreover, this study generated important information about future deforestation by predicting the magnitude of change and location where deforestation would be expected to happen. This was very interesting finding that would support a decision-making process to take corrective measure ahead of time to avoid expected deforestation.

\section{Recommendations}

The deforestation in the area resulted in different social and environmental impacts. In line to this, the following key recommendations were suggested.

The Oromia Forest and Wildlife Enterprise at District level and NGOs should be aware of declining of resource and strategize to avoid deforestation by strengthening capacity of Community Based Forest Management Cooperative by providing trainings and awareness creation that gears towards bringing better forest protection.

The deforestation in the area has resulted in shortage of fuel woods and it is therefore recommended that fuel efficient technologies need to supply for community with affordable price. Towards this, the Woreda Energy Promotion Office is advised to work with NGOs, those who work in the area like Farm Africa and SOS Sahel Ethiopia, because those NGOs have experience of subsidizing adopting of fuel saving stoves.

Implementation of participatory forest management in Delo Mena District has generated strong evidence that PFM contributes to reducing deforestation. Hence, OFWE Headquarter Office ought to practically demonstrate benefit sharing of forest timber products and carbon revenue and the District office of OFWE breach should provide strong technical backstopping and law enforcement in collaboration with judiciary and policy offices that are working at District level. Socio economic impacts of deforestation in this study area were measured based on people's perception about trend of impacts. In the future study, it is recommended that household level impacts need to be investigated.

\section{Conflicts of Interest}

The authors declare no conflicts of interest regarding the publication of this paper.

\section{References}

[1] Mishra, V.N., Rai, P.K. and Mohan, K. (2014) Prediction of Land Use Changes Based on Land Change Modeler Using Remote Sensing: A Case Study of Muzaffarpur (Bihar), India. Journal of the Geographical Institute "Jovan Cvijic" SASA, 64, 111-127. https://doi.org/10.2298/IJGI1401111M 
[2] Zhan, J., Liu, J., Lin, Y., Feng, W.Y. and Ma, E. (2014) Chapter 2, Land Use Change Dynamics Model Compatible with Climate Models. https://doi.org/10.1007/978-3-642-54876-5_2

[3] Kumar, S.K., Valasala, S., Subrahmanyam, V.J., Mallampati, M., Shaik, K. and Ekkirala (2015) Prediction of Future Land-Use Land-Cover Changes of Vijayawad City Using Remote Sensing and GIS. International Journal of Innovative Research in Advanced Engineering, 2, 91-97.

[4] Mas, J.F. (1999) Monitoring Land-Cover Changes: Comparison of Change Detection Techniques. International Journal of Remote Sensing, 20, 139-152. https://doi.org/10.1080/014311699213659

[5] Shi, H., Yu, K., Feng, Y., Dong, X., Zhao, H. and Deng, X. (2012) RS and GIS-Based Analysis of Landscape Pattern Changes in Urban-Rural Ecotone: A Case Study of Daiyue District, Tai'an City, China. Journal of Landscape Research, 4, 20-23.

[6] Efrem, G. (2010) Land-Use and Land-Cover Dynamics and Rural Livelihood Perspectives, in the Semi-Arid Areas of Central Rift Valley of Ethiopia, Faculty of Forest Sciences Department of Forest Resource Management Umeå. Doctoral Dissertation, Swedish University of Agricultural Sciences, Sweden.

[7] FAO Food and Agriculture Organization of the United Nations (2016) Global Forest Resources Assessment 2015: How Are the World's Forests Changing? Second Edition, Rome.

[8] Kaimowitz, D. and Angelsen, A. (1998) Economic Models of Tropical Deforestation Review by the Center for International Forestry Research. (In Indonesia)

[9] Abebe, S. (2005) Land-Use and Land-Cover Change in Headstream of Abbay Watershed, Blue Nile Basin, Addiss Ababa University, Ethiopia.

[10] Usharani, V., Sarala, P., Poonguzali, J. and Sharmila, G. (2012) Role of Remote Sensing and Geographic Information System in Natural. IJCS New Liberty.

[11] Rajan, D. (2006) Understanding the Drivers Affecting Land Use Change in Ecuador: Application of the Land Change Modeler Software. PhD Dissertation, University of Edinburgh, Edinburgh.

[12] Javed, A., Jamal, S. and Khandey, M.Y. (2012) Climate Change Induced Land Degradation and Socio-Economic Deterioration: A Remote Sensing and GIS Based Case Study from Rajasthan, India. Journal of Geographic Information System, 4, 219-228. https://doi.org/10.4236/jgis.2012.43026

[13] MengistieKindu, S., DemelTeketay, T. and Knoke, T. (2013) Land Use/Land Cover Change Analysis Using Object-Based Classification Approach in Munessa-Shashemene Landscape of the Ethiopian Highlands. Journal of Remote Sensing, 5, 2411-2435. https://doi.org/10.3390/rs5052411

[14] Birhanu, A. (2014) Environmental Degradation and Management in Ethiopian Highlands: Review of Lessons Learned. International Journal of Environmental Protection and Policy, 2, 24-34. https://doi.org/10.11648/j.ijepp.20140201.14

[15] Hussien, A.O. (2009) Land Use and Land Cover Change, Drivers and Its Impact: A Comparative Study from Kuhar Michael and LencheDima of Blue Nile and Awash Basins of Ethiopia. MSc Thesis, Faculty of the Graduate School of Cornell University.

[16] Aithal, B.H., Vinay, S. and Ramachandra, T.V. (2013) Prediction of Land Use Dynamics in the Rapidly Urbanising Landscape Using Land Change Modeler. Advances in Computer Science, AETCAS, NCR, Delhi, 13-14 December 2013.

[17] Pontius, R.G. and Chen, H. (2006) GEOMOD Modelling, Land-Use \& Cover 
Change Modelling. Clark University, Worcester.

[18] Behailu, A. (2010) Land Use and Land Cover Analysis and Modeling in South Western Ethiopia: The Case of Selected Resettlement Kebeles in GimboWoreda. MSc Thesis, Addis Ababa University, Addis Ababa.

[19] Veldkamp, A. and Lambinb, E.F. (2001) Predicting Land-Use Change. Agriculture, Ecosystems and Environment, 85, 1-6. https://doi.org/10.1016/S0167-8809(01)00199-2

[20] Rodriguez, N., Armenteras, D. and Retana, J. (2011) Land-Use Land-Cover Change in the Colombian Andes: Dynamics and Future Scenarios.

[21] Mas, J.C., Kolb, M., Paegelow, M., Olmedo, M.C. and Hout, T. (2014) Modeling Land Use and Cover Changes: A Comparison of Conceptual Approaches and Software, Environmental Modeling and Software. Elsevier, Amsterdam, Vol. 51, 94-111.

[22] Yohannes, K., Stahlmann, R. and Beierkuhnle, C. (2012) Vegetation Dynamics, and Land-Use and Land-Cover Change in the Bale Mountains, Ethiopia. Environmental Monitoring and Assessment, 184, 7473-7489.

https://doi.org/10.1007/s10661-011-2514-8

[23] Farm-SOS (2013) Bale Mountains Eco-Region Reduction of Emission from Deforestation and Forest Degradation (REDD+) Project, Addis Ababa, Ethiopia.

[24] Alemu, M., Suryabhagavan, K.V. and Balakrishinan, M. (2012) Assessments of Cover Change in the Harenna Habitats in the Bale Mountains Ethiopia, Using GIS and Remote Sensing. International Journal of Ecology and Environment Science, 38, 39-45.

[25] Bale Ecoregion Sustainable Management Program (BERSMP) (2008) Community Profile and Settlement Dynamics in Four Woredas of Oromiya National Regional State: Dallo Mena, HaranaBuluq, Goba and Nansabo Consultancy Study. FARM Africa and SOS Sahel, Addis Ababa.

[26] Abera, W. (2009) Status of Traditional Agroforestry and Its Future Potential Development as Buffer Zone Agroforestry for the Natural Forest Conservation in Burkitu Peasant Association, Oromia, Ethiopia. MSc Thesis, College of Forestry and Natural Resource, Wondo Genet, Hawassa University, Hawassa.

[27] Mehadi, S., Beriso, M. and Worku, Y. (2016) Full Length Research Paper Participatory Variety Selection of Improved Tomato (Lycopersicumesculentum Mill.) Varieties in the Lowlands of Bale, South-Eastern Ethiopia. African Journal of Agricultural Economics and Rural Development, 4, 458-462.

[28] Dereje, T. (2015) Migration and Conservation in the Bale Mountains Ecosystem IISD Report. International Institute for Sustainable Development (IISD).

[29] Tadesse, D. and Garedew, F. (2001) Vegetation Zoning of Bale. DGIS-WWF Forest Conservation in High Priority Areas of Ethiopian Project.

[30] Bureau of Finance and Economic Development (BOFED) (2008) Socio-Economic Profile of Bale Zone: Oromia State Government.

[31] Central Statistical Agency (CSA) (2013) Population Projection of Ethiopia for All Regions at Wereda Level from 2014-2017. Addis Ababa. http://www.csa.gov.et

[32] Ikusemoran, M. (2009) Land Use and Land Cover Change Detection in the Kainji Lake Basin Nigeria Using Remote Sensing and GIS Approach. Bayero Journal of Pure and Applied Sciences, 2, 83-90.

[33] Prakasam, C. (2010) Land-Use and Land-Cover Change Detection through Remote Sensing Approach: A Case Study of Kodaikanal Taluk, Tamil Nadu. International Journal of Geomatics and Geosciences, 1, 150-158. 
[34] Beza, T.A. (2011) Land-Cover Dynamics in Savanna Ecosystem of Borena Ethiopia. Thesis of Master of Science in Geospatial Technologies, Institute for Geoinformatics University of Münster, Münster.

[35] ERDAS (1999) ERDAS Field Guide Revised and Expanded. 5th Edition, ERDAS Inc., Atlanta.

[36] Coppin, P.R. and Marvin, E.B. (1996) Change Detection in Forest Ecosystems with Remote Sensing Digital Imagery. Remote Sensing Reviews, 13, 207-234. https://doi.org/10.1080/02757259609532305

[37] Yohannes, T., Awas, T. and Demisew, S. (2011) Survey and Ocumentation of the Potential and Actual Invasive Alien Plant Species and Other Biological Threats to Biodiversity in Awash National Park, Ethiopia. Management of Biological Invasions, 2, 3-14. https://doi.org/10.3391/mbi.2011.2.1.01

[38] Yohanis, K. and D'Huart, J.P. (2014) Assessment of the Present Distribution of the Forest Hog (Hylochoerusmeinertzhageni) in Ethiopia. Journal of Mountain Ecolo$g y, 3,46-48$.

[39] Were, K.O. (2008) Monitoring Spatio-Temporal Dynamics of Land Cover Changes in Lake Naivasha Drainage Basin, Kenya. MSc Thesis.

[40] Mallupattu, P.K. and Reddy, J.R.S. (2013) Analysis of Land Use/Land Cover Changes Using Remote Sensing Data and GIS at an Urban Area, Tirupati, India. The Scientific World Journal, 2013, Article ID: 268623. https://doi.org/10.1155/2013/268623

[41] Gonzales Inca, C.A. (2009) Assessing the Land Cover and Land Use Change and Its Impact on Watershed Services in a Tropical Andean Watershed of Peru. Master Thesis, University of Jyväskylä, Peru.

[42] Agyakwa, K.T. (2014) Assessing the Effect of Land Use Land Cover Change on Weija Catchment. MSc Thesis, Kwame Nkrumah University of Science and Technology.

[43] Eastman, J.R. (2012) IDRSISelva Manual, IDRSI Production, Clark University, USA.

[44] Ahmed, B., Ahmed, R. and Zhu, X. (2013) Evaluation of Model Validation Techniques in Land Cover Dynamics. International Journal of Geo-Information, 2, 577-597. https://doi.org/10.3390/ijgi2030577

[45] Arekhi (2011) Modeling Spatial Pattern of Deforestation Using GIS and Logistic Regression: A Case Study of Northern Ilam Forests, Ilam Province, Iran. African Journal of Biotechnology, 10, 16236-16249.

[46] Megahed, Y., Cabral, P., Silva, J. and Caetano, M. (2015) Land Cover Mapping Analysis and Urban Growth Modeling Using Remote Sensing Techniques in Greater Cairo Region, Egypt. ISPRS International Journal of Geo-Information, 4, 1750-1769. https://doi.org/10.3390/ijgi4031750

[47] Hepinstall, J.A., Alberti, M. and Marzluff, J.M. (2008) Predicting Land Cover Change and Avian Community Responses in Rapidly Urbanizing Environments.

[48] Al-sharif, A. and Pradhan, B. (2013) Monitoring and Predicting Land Use Change in Tripoli Metropolitan City Using an Integrated Markov Chain and Cellular Automata Models in GIS.

[49] Alba, H.D. (2011) Deforestation in the Kayabi Indigenous Territory: Simulating and Predicting Land Use and Land Cover Change in Brazilian Amazon. MSc Thesis, London University, London.

[50] Khoi, D.D. and Murayama, Y. (2010) Forecasting Areas Vulnerable to Forest Conversion in the Tamdao National Park Region, Vietnam. Journal of Remote Sensing, 
2, 1249-1272. https://doi.org/10.3390/rs2051249

[51] Adepoju, M.O., Millington, A.C. and Tansey, K.T. (2006) Land Use/Land Cover Cahnge Detection in Metroploitian Lagos (Nigeria): 1984-2000. AASPRS 2006 Annual Conference, Reno Nevada, 1-5 May 2006.

[52] Costanza, R. and Ruth, M. (1998) Using Dynamic Modeling to Scope Environmental Problems Build Consensus. Environmental Management, 22, 183-195. https://doi.org/10.1007/s002679900095

[53] Labs, C. (2009) The Land Change Modeler for Ecological Sustainability. IDRISI Focus Paper, Clark University, Worcester.

[54] National Academies of Sciences Engineering and Medicine (NASEM) (2014) Improving Land Change Modeling Opportunities and Research Requirements for Advancing Land Change Modeling. Washington DC.

[55] Eastman, R.J. (2003) IDRISI Kilimanjaro Tutorial Clark Labs. Clark University, Worcester.

[56] Adedeji, O.H., Tope, A.O. and Abegunde, O.L. (2015) Assessing and Predicting Changes in the Status of Gambari Forest Reserve, Nigeria Using Remote Sensing and GIS Techniques. Journal of Geographic Information System, 7, 301-318. https://doi.org/10.4236/jgis.2015.73024

[57] Maria, A. (1997) Introduction to Modeling and Simulation.

[58] Sun, H., Forsythe, W. and Waters, N. (2007) Modeling Urban Land Use Change and Urban Sprawl: Calgary, Alberta, Canada. Networks and Spatial Economics, 7, 353-376. https://doi.org/10.1007/s11067-007-9030-y

[59] Olsonm, J.M., Misana, S., Campbell, D.J., Mbonile, M. and Mugisha, S. (2004) Land Use Change, Impacts and Dynamics (LUCID). Project Working Paper Number 48, International Livestock Research Institute, Nairobi.

[60] Simon, A. (2000) Participatory Rural Appraisal Training Manual.

[61] BERSMP (2008) Bale Mountains National Park General Management Plan. Frankfurt Zoological Society.

[62] Keenan, R.J., Reams, G.A., Achard, F., Freitas, J.V., Grainger, A. and Lindquist, E. (2015) Review and Synthesis, Dynamics of Global Forest Area: Results from the FAO Global Forest Resources Assessment 2015. Journal of Forest Ecology and Management, 352, 9-20.

[63] FAO (Food and Agriculture Organization of the United Nations) (2005) State of World's Forests. Food and Agriculture Organization of the United Nations, Rome.

[64] Fekadu, G. (2015) Forest Loss and Climate Change in Ethiopia. Research Journal of Agriculture and Environmental Management, 4, 216-224.

[65] Geist, H.J. and Lambin, E.F. (2001) What Drives Tropical Deforestation? Meta-Analysis of Proximate and Underlying Causes of Deforestation Based on Subnational Case Study Evidence. LUCC Report Series No. 4, LUCC International Project Office, University of Louvain, Louvain.

[66] De Sherbinin, A. (2002) Land-Use and Land-Cover Change. A CIESIN Thematic Guide, Center for International Earth Science Information Network of Columbia, Palisades.

[67] Rademaekers, K., Eichler, L., Berg, J., Obersteiner, M. and Havlik, P. (2010) Study on the Evolution of Some Deforestation Drivers and Their Potential Impacts on the Costs of an Avoiding Deforestation Scheme Final Consultancy Report for European Commission. 
[68] MEFCCE (Ministry of Environment, Forest, Climate Change of Ethiopia) (2016) Ethiopia's Forest Reference Level Submission Report to the United Nations Framework Convention for Climate Change.

[69] Ararsa, R. (2015) Fuelwood Consumption and Its Environmental Impacts: The Case of Bale Eco-Region, Oromia Regional State, South Eastern Ethiopia. MSc Thesis, Wondo Genet College of Forestry and Natural Resources, Hawassa University, Hawassa.

[70] Briassoulis, H. (2000) Analysis of Land Use Change: Theoretical and Modeling Approaches. Regional Research Institute, West Virginia University, Morgantown.

[71] EPCC (Ethiopian Population Census Commission) (2008) Summary and Statistical Report of the 2007 Population and Housing Census: Population Size by Age and Sex. United Nations Population Fund (UNFPA), Addis Ababa.

[72] Chakravarty, S., Ghosh, S.K., Suresh, C.P., Dey, A.N. and Shukla, G. (2012) Deforestation: Causes, Effects and Control Strategies. In: Okia, C.A., Ed., Global Perspectives on Sustainable Forest Management, InTech, London, 4-28. https://doi.org/10.5772/33342

[73] Ayele, G. (2011) Analysis of Sustainable Forest Resources Management within Bale Eco-Region Approach: The Case of Waberokebele, Delomenaworeda, Oromia Regional State, Ethiopia.

[74] USAID United States Agency for International Development (2008) Ethiopia Biodiversity and Tropical Forests Assessment. http://usaid.gov/pdf_docs/PNADM939.pdf

[75] Tsegaye, T., Arsema, A. and Irwin, B.C. (2007) Watching the Tree Grow: Participatory Forest Management Takes Root in Africa. Proceedings. International Conference on Poverty Reduction and Forests, Bangkok, September 2007, 221-238.

[76] Tindan, P.D. (2013) The Causes of and Impact from Deforestation on Local Level Sustainable Forest Management in Ghana. A Survey of Dwease and Praaso Communities in the Ashanti Region. MSc Thesis, University of Agder, Agder.

[77] Amdissa, T. (2006) Agriculture, Growth and Poverty Reduction in Ethiopia: Policy Processes around the New PRSP (PASDEP).

[78] FAO (Food and Agriculture Organization of the United Nations) (2010) Global Forest Resources Assessment. FOA Forestry Paper 2010 Main Report 163, Rome.

[79] Farm Africa (2016) Factors Affect Women's Participation in Management of Forest Resources and Decision Making Process in REDD+ Project in Bale Mountains Eco-Region. Gender Study Report, Fromseas Share Company Plc.

[80] Farm-SOS (2015) The Bale Mountains Eco-Region Reduction of Emission from Deforestation and Forest Degradation. Project Designed Document, Addis Ababa. 